\title{
Refuge
}

Canada's Journal on Refugees

Revue canadienne sur les réfugiés

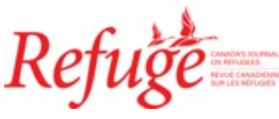

\section{Resettling Refugees through Community Sponsorship: A Revolutionary Operational Approach Built on Traditional Legal Infrastructure}

\section{Jennifer Bond and Ania Kwadrans}

Volume 35, Number 2, 2019

Private Sponsorship in Canada

URI: https://id.erudit.org/iderudit/1064822ar

DOI: https://doi.org/10.7202/1064822ar

See table of contents

Publisher(s)

Centre for Refugee Studies, York University

ISSN

0229-5113 (print)

1920-7336 (digital)

Explore this journal

Cite this article

Bond, J. \& Kwadrans, A. (2019). Resettling Refugees through Community

Sponsorship: A Revolutionary Operational Approach Built on Traditional Legal Infrastructure. Refuge, 35(2), 86-108. https://doi.org/10.7202/1064822ar

\section{Article abstract}

More than a dozen states are exploring the potential of introducing community sponsorship programs as a way of contributing to the global refugee protection regime. This article provides a comparative analysis of the legal and administrative frameworks that have underpinned the introduction of community sponsorship in four diverse countries: Canada, the United Kingdom, New Zealand, and Argentina. We also briefly examine the introduction of co-sponsorship in the United States, a country without any formal national program. We conclude that while community sponsorship programs have the potential to revolutionize refugee resettlement, their operationalization is not contingent on revolutionary legal infrastructure.
Copyright (c) Refuge: Canada’s Journal on Refugees, 2019

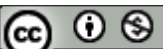

This document is protected by copyright law. Use of the services of Erudit (including reproduction) is subject to its terms and conditions, which can be viewed online.

https://apropos.erudit.org/en/users/policy-on-use/ 


\title{
Resettling Refugees through Community Sponsorship:
}

\section{A Revolutionary Operational Approach Built on Traditional Legal Infrastructure}

\author{
JENNIFER BOND and ANIA KWADRANS ${ }^{1}$
}

\section{Abstract}

More than a dozen states are exploring the potential of introducing community sponsorship programs as a way of contributing to the global refugee protection regime. This article provides a comparative analysis of the legal and administrative frameworks that have underpinned the introduction of community sponsorship in four diverse countries: Canada, the United Kingdom, New Zealand, and Argentina. We also briefly examine the introduction of co-sponsorship in the United States, a country without any formal national program. We conclude that while community sponsorship programs have the potential to revolutionize refugee resettlement, their operationalization is not contingent on revolutionary legal infrastructure.

\section{Résumé}

Plus d'une douzaine de pays à travers le monde envisagent activement la possibilité d'introduire des programmes de parrainage communautaires comme manière de contribuer au régime global de protection des réfugiés. Cet article offre une analyse comparative des cadres légaux et administratifs sur lesquels s'est appuyée l'introduction du parrainage communautaire dans quatre pays: le Canada, le Royaume-Uni, la Nouvelle-Zélande et l'Argentine. Nous examinons aussi brièvement l'introduction du co-parrainage aux États-Unis, un pays qui ne possède pas formellement de programme national. Nous concluons que bien que les programmes de parrainage communautaires aient le potentiel de révolutionner la réinstallation des réfugiés, leur mise en oeuvre ne dépend pas d'une infrastructure juridique révolutionnaire.
() Jennifer Bond and Ania Kwarrans, 2019. This open-access work is licensed under a Creative Commons Attribution-NonCommercial 4.0 International Licence, which permits use, reproduction, and distribution in any medium for non-commercial purposes, provided the original authorship is credited and the original publication in Refuge: Canada's Journal on Refugees is cited.
Cette œuvre en libre accès fait lobjet d'une licence Creative Commons Attribution-NonCommercial 4.o International License, laquelle autorise l'utilisation, la reproduction et la distribution de l'œuvre sur tout support à des fins non commerciales, pourvu que l'auteur ou les auteurs originaux soient mentionnés et que la publication originale dans Refuge: revue canadienne sur les réfugiés soit citée. 


\section{Introduction}

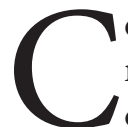
ommunity sponsorship programs empower ordinary citizens to welcome and integrate refugee newcomers into their communities. More than a dozen countries are exploring the introduction of these programs as part of their global commitments to refugee protection, and each exploration includes an assessment of feasibility-including considering what statutory, ${ }^{2}$ regulatory, ${ }^{3}$ and policy ${ }^{4}$ structures are required to operationalize the unique model. This article fills a gap in academic literature and policy documents by providing a comparative analysis of the legal and administrative frameworks that have underpinned the introduction of community sponsorship programs in four diverse countries: Canada, the United Kingdom, New Zealand, and Argentina. We also briefly examine the United States, a country that has recently seen the localized introduction of sponsorship-style programs, despite the absence of a dedicated national scheme or any formal framework. As discussed below, we term the us model "co-sponsorship."

Since the inception of Canada's Private Sponsorship of Refugees (PSR) Program in 1979, ordinary individuals have resettled over 300,000 refugees to large and small communities across the country. Comparative data emanating from this program over the past forty years demonstrate that sponsored refugees have better and quicker integration outcomes than refugees resettled through more traditional government programs. 5 Community sponsorship also engages a broad range of Canadian citizens and enjoys consistent bipartisan political support. ${ }^{6}$ Refugee sponsorship received increased attention in late 2015, when a brewing political crisis over refugees spilled into the mainstream media 7 and mobilized millions of people around the world looking to directly assist the vulnerable individuals flashing across their screens each day. ${ }^{8}$ In Canada, sponsorship provided an ideal vehicle to organize and leverage this mobilization and-following a time-bound political commitment by a new national government ${ }^{9}$ - tens of thousands of Syrians were sponsored to the country in just a few months. ${ }^{10}$ Canada's PSR Program also provided a unique channel to sustain and broaden this engagement: since 2015, over two million Canadians from over 400 communities have sponsored refugees ${ }^{11}$ - extraordinary figures that hint at the potential power and scope of the community sponsorship model.

In September 2016 the government of Canada, the UN Refugee Agency (UNHCR), and the Open Society Foundations announced the formation of the Global Refugee Sponsorship Initiative (GRSI), a partnership aimed at sharing the community sponsorship model, and supporting its adoption around the world. ${ }^{12}$ The Giustra Foundation and the University of Ottawa joined the GRsi before it formally launched in December 2016, and the new partnership articulated three goals: increasing and improving refugee resettlement; strengthening and supporting local host communities; and improving the narrative surrounding refugees and newcomers. ${ }^{13}$ In its first two years of operation, the GRSI worked with over twenty countries around the world, supporting community and government stakeholders as they assessed feasibility, designed, piloted, and/or implemented sponsorship programs. ${ }^{14}$ Jennifer Bond co-founded the GRSI and serves as its chair, while Ania Kwadrans has played a critical role on the team since the initiative launched. While this article does not directly draw on that work, our understanding of community sponsorship is deeply informed by it.

The GRSI's formation, and its subsequent high level of activity, is only one indication of growing global interest in community sponsorship programs. Increasing engagement is also formally reflected in statements and initiatives by the European Union ${ }^{15}$ and in the final draft of the Global Compact on Refugees (GCR), a multilateral agreement that explicitly encourages states to "establish private or community sponsorship programmes ... including community-based programmes promoted through the Global Refugee Sponsorship Initiative." 16 Momentum is also visible in individual countries, as is clearly reflected in a strong joint statement issued by immigration ministers from Canada, the United Kingdom, Ireland, Argentina, Spain, and New Zealand. The statement notes the benefits of community sponsorship and encourages other countries to adopt these programs. ${ }^{17}$

Collective experience with the process for introducing new community sponsorship programs is growing, but nascent. The case studies presented in this article aim to advance the field by providing examples of varying technical structures that have facilitated introduction of sponsorship across a range of countries. Each of our case studies explores legislation, executive announcements and orders, and any operational infrastructure that may have been established through regulation and policy documents, and subsequently implemented by government organizations or entities with delegated authority. On the basis of our five country examples, we conclude that while the legislative and policy nuances of each community sponsorship program have emerged in ways tailored to each state's particular context, the frameworks that underpin these programs contain key similarities, including reliance on the same basic infrastructure as traditional refugee resettlement schemes.

\section{Definitions and Methodology}

The terms community sponsorship, private sponsorship, and refugee sponsorship have not been universally defined, ${ }^{18}$ resulting in conceptual confusion amongst stakeholdersa topic Jennifer Bond is exploring in a dedicated piece of 
writing. ${ }^{19}$ For the purposes of this contribution, we define community sponsorship programs as programs that empower groups of ordinary individuals-as opposed to governments or professionalized agencies-to lead in welcoming, supporting, and integrating refugees. ${ }^{20}$ While policy design features vary between countries, ${ }^{21}$ the basic model is a "publicprivate partnership between governments who, [at minimum,] facilitate legal admission of refugees, and private actors who provide financial, social and/or emotional support to receive and settle [those] refugees into [their] community."22

Under our conceptualization of community sponsorship, the model responds to the observation that "by redefining basic human needs as 'problems' that only professionals can resolve ... over-professionalization alienates people from the helping relationships they could establish with neighbours and kin." ${ }^{23}$ The deep engagement and high degree of responsibility undertaken by individual refugee sponsors repositions newcomers from vulnerable outsiders whom private individuals watch fail or succeed, to partners in a project of collective interests: the newcomers' success is inherently also the sponsors' success. This profound partnership divides sponsorship programs from other forms of refugee support, including those that rely heavily on volunteers but are fundamentally led by paid professionals.

This article presents the legal and policy architecture that states have used to enable citizen sponsors to lead in resettling refugees. In addition to exploring four countries with government-created, national sponsorship programs, we also briefly examine the United States, a country with a large refugee resettlement program but no formal community sponsorship scheme at the legislative or policy level. Despite this absence, several local resettlement organizations in the United States have developed de facto sponsorship-style initiatives by sub-delegating authority in a way that manifests the type of citizen-led process at the core of our understanding of sponsorship. Since professionalized agencies retain official responsibility for newcomers' integration, these programs do not fall within the scope of our definition of community sponsorship, and we thus present them using a different but related term: co-sponsorship.

We also deliberately restrict our analysis to countries that have introduced sponsorship programs in the context of resettlement-the relocation of a refugee from her country of asylum to a third country, usually with the support of the UN Refugee Agency (UNHCR). ${ }^{24}$ Resettlement programs are voluntary: while the Refugee Convention codifies obligations for states to protect certain non-nationals who claim asylum from within their territory, 25 they are not legally obliged to offer protection to refugees who remain in the jurisdiction of other states. Despite this lack of formal requirement, the international community has repeatedly recognized the need for more "equitable sharing" of responsibility for refugees, ${ }^{26}$ and over forty states have established resettlement programs as one way of contributing to this objective. ${ }^{27}$ Each resettlement country has established its own distinct national procedures for operationalizing its program, but Canada's PSR Program was, for many decades, unique because of the way that it empowered ordinary individuals to take primary responsibility for all aspects of welcoming and integrating newcomers. ${ }^{28}$

Our focus on community sponsorship in the context of resettlement means that our analysis does not consider community-driven models that support asylum seekers 29 or other populations of newcomers. ${ }^{30}$ We also consciously omit programs where the "welcomers" are exclusively family members, ${ }^{31}$ as well as programs where costs are shared between private and public actors, but integration is led primarily by government or professionalized refugee support organizations as opposed to community groups or individuals. ${ }^{32}$ Finally, because we are interested in exploring the infrastructure that has enabled the creation of sustainable, national sponsorship programs, we have not considered ad hoc, community-driven initiatives negotiated with single civil society groups via time-limited agreements. 33

This article provides a technical analysis of the statutory, regulatory, and policy structures that were required to initially operationalize a selection of community sponsorship programs. As a result, we take a historical view of our first case study-Canada-and examine the legislative changes that created the foundations for the world's largest and longest-running community sponsorship program.

\section{Canada}

\section{Enabling Legislation and Orders}

Canada acceded to the 1951 Refugee Convention in 1969. ${ }^{34}$ A detailed review of Canada's immigration policy followed in 1973, culminating in the 1976 Immigration Act, 35 which introduced Canada's first official resettlement program. ${ }^{36}$ Prior to 1976 , refugee resettlement was based on ad hoc decisions and Cabinet orders-in-council. ${ }^{37}$ The new legal framework explicitly recognized refugees as a distinct class of migrants and included a more transparent approach for overseas selection and resettlement on humanitarian grounds. ${ }^{8}$ Refugees who met the requirements of the Act were to be granted permanent resident status upon arrival to the country. ${ }^{39}$ Since 1959, Canada has resettled over 700,000 refugees from all over the world. $4^{\circ}$

The 1976 resettlement framework also included a provision that explicitly enabled refugee resettlement through community sponsorship..$^{41}$ Specifically, the new Immigration Act gave power to the Governor-in-Council to make regulations "prescribing classes of persons whose applications for landing may be sponsored by Canadian citizens [or] 
... permanent residents", 42 and "establishing the requirements to be met by any [sponsoring] person or organization including the provision of an undertaking to assist any such Convention refugee, person or immigrant in becoming successfully established in Canada." 43 These brief statutory references provided the foundation for the world's first community sponsorship program.

Canada's new approach to resettlement was quickly operationalized: in December 1978 the country pledged to accept 5,000 refugees from Vietnam, Cambodia, and Laos as part of an international response to the forced displacement of millions of Indochinese refugees. ${ }^{44}$ The scale and visibility of the crisis continued to increase, however, prompting public calls for the government to further expand its commitment. ${ }^{45} \mathrm{In}$ June 1979 the Canadian government announced that it would admit 12,00o Indochinese refugees-8,000 of whom would be government-assisted and 4,000 of whom would be privately sponsored by individual groups and organizations. ${ }^{46}$ That same month, the commitment was increased further to 50,000 resettled refugees by the end of 1980.47 To manage the rapidly increasing numbers, the government established a Special Refugee Task Force to specifically manage Canada's resettlement of Indochinese refugees. $4^{8}$ It also pledged to meet its ambitious new targets by offering a "matching" model to the Canadian public, whereby it would admit one Indochinese refugee to the government-supported stream for everyone who was privately sponsored. With this commitment, the country's new PSR Program rapidly took hold as one of Canada's principal resettlement mechanisms. 49

\section{Regulations and Program Administration}

Canada's Immigration Regulations, 1978,50 contained provisions that contoured the country's new PSR Program,51 including defining the eligibility parameters for a sponsored refugee $^{52}$ and specifying that sponsor groups must be composed of at least five adult Canadian citizens or permanent residents (or be a Canadian corporation) residing or located in the expected community of settlement. ${ }^{53}$ Eligible groups were permitted to resettle refugees after signing a written undertaking that they would provide one year of financial and settlement support 54 and demonstrating sufficient financial resources and a plan for "adequate arrangements ... for the reception of the Convention refugee and his accompanying dependants." 55 The new regulations were in place before the Governor-in-Council designated the first three classes of refugees eligible for the program on 29 January 1979. ${ }^{56}$

Faith communities and ethno-cultural groups in Canada had a long history of supporting resettled refugees before the PSR program was introduced 57 and were well positioned to support the influx of Indochinese newcomers through the new sponsorship stream. These national organizations sought ways to leverage their own infrastructure, and beginning in March 1979, developed master agreements" with the Canadian government ${ }^{58}$ that allowed them to authorize individual congregations across Canada to sponsor Indochinese refugees. 59 These agreements also allowed the government of Canada to delegate sponsor-screening responsibilities to agreementholding organizations, ${ }^{60}$ while government officials retained responsibility for vetting refugees and thousands of "Groups of Five" who were unaffiliated with a larger sponsorship organization. ${ }^{61}$ Within weeks, the government had signed agreements with almost all the national church bodies in Canada. ${ }^{62}$

Today Canada's refugee law is governed by the Immigration and Refugee Protection Act, $2001^{63}$ (IRPA) and its associated Immigration and Refugee Protection Regulations, $2002^{64}$ (IRPR). The IRPA retains the central provision that enables sponsorship, ${ }^{65}$ and the IRPR sets out, inter alia, the eligibility criteria for sponsors ${ }^{66}$ and sponsored refugees. ${ }^{67}$ The dual track set in 1979 between master agreement holders (today, "sponsorship agreement holders") and Groups of Five continues to underpin the program's modern form. ${ }^{68}$ However, Canada's sponsorship program has diversified and today includes dedicated and specialized programs for sponsoridentified refugees; UNHCR-referred refugees; ${ }^{69}$ individuals persecuted for sexual orientation or gender identity; $7^{70}$ refugees with complex medical needs $;{ }^{71}$ urgent cases; $;^{72}$ and post-secondary students. ${ }^{73}$ Despite this evolution, the core of all of Canada's community sponsorship programs remains robust citizen responsibility and empowerment.

As described above, the world's first community sponsorship program was formed simultaneously with, and integrated into, Canada's new national resettlement program. Its unique referral mechanism permitting sponsors to identify refugees they wished to resettle was enabled by an explicit provision in the 1976 Immigration Act, which also delineated very generally the parameters through which persons could seek protection, and gave scope for regulations to fill in myriad details. ${ }^{74}$ This model underscores the minimal legislative framework that was necessary to facilitate the introduction of this radically different approach to refugee resettlement.

Unlike Canada, our next two case studies-the United Kingdom and New Zealand-each introduced community sponsorship into pre-existing and well-established refugee resettlement infrastructure. In the following sections, we examine the distinct approach each country took to doing so.

\section{United Kingdom}

\section{Enabling Legislation and Orders}

The United Kingdom ratified the Refugee Convention on 11 March $1954 .{ }^{75}$ It has been resettling refugees since the early 1970 via a combination of two informal programs ${ }^{76}$ and ad hoc initiatives to respond to specific humanitarian 
crises. 77 Since 1971 the legal basis for refugees to be admitted to, and stay in, the United Kingdom-including through resettlement-has been the Immigration Act, $1971 .^{78}$ The Act requires any individuals who are neither UK citizens nor members of the European Economic Area to obtain leave 79 from UK authorities before entering the country. ${ }^{80}$

Building on its three decades of experience with informal and ad hoc resettlement programs, the United Kingdom formalized its approach to resettlement in 2004 by introducing the Gateway Protection Program (GPP). ${ }^{81}$ The GPP was operationalized and continues to function by virtue of section 59 of the Nationality, Immigration and Asylum Act, 2002 (NIA), ${ }^{82}$ which enables the secretary of state to "participate in [projects] designed to ... facilitate co-operation between States in matters relating to migration" 83 and to "arrange or assist the settlement of migrants." 84 The NIA further specifies that the secretary of state may provide financial support to international organizations in the United Kingdom for their migration-related projects, and may partner with other governments that advance similar programs. ${ }^{85}$

The same broad provision in the NIA that underpinned the GPP also facilitated the more recent introduction of two newer resettlement programs: the Vulnerable Persons Resettlement Scheme (VPRS), and the Vulnerable Children's Resettlement Scheme (VCRS). ${ }^{86}$ The VPRS was announced on 29 January 2014 in a statement to Parliament by the home secretary, ${ }^{87}$ in which she committed to creating a new resettlement program for Syrian refugees. The home secretary did not initially quantify the scope of the initiative, but on 2 September 2015 it was announced that the vPRS would resettle 20,000 Syrians by $2020 .{ }^{88}$ In July 2017 the scope of the program was expanded to include refugees not only of Syrian nationality but also others affected by the Syrian conflict. ${ }^{89}$ The VPRS relies on the UNHCR to refer eligible refugees residing in Egypt, Iraq, Turkey, Jordan, and Lebanon. ${ }^{\circ 0} \mathrm{~A}$ crossgovernment Syrian Resettlement Team that includes the UK Home Office, the Department for Communities and Local Government, the Department for International Development, and several other ministries was created to implement the program..$^{91}$ The United Kingdom also pledged to resettle 3,000 at-risk children and their families from the Middle East and North Africa by 2020, a commitment that resulted in the creation of the VCRS. ${ }^{22}$ Refugees resettled through the VPRS and VCRs programs are granted refugee status, which enables them to work and to access benefits in the United Kingdom. ${ }^{93}$ After five years of residency in the United Kingdom, resettled refugees may apply for indefinite leave to remain in the country. 94 The United Kingdom resettled over 25,000 refugees from all over the world between 2003 and 2018.95

The UK community sponsorship program was introduced as a component of the VPRS and the VCRS in a separate and very brief political statement by the home secretary at the Conservative Party conference on 6 October 2015. There, it was announced that the United Kingdom would "develop a community sponsorship scheme ... to allow individuals, charities, faith groups, churches and businesses to support refugees directly." 96 This statement launched work to create a robust national sponsorship program. Further, by putting no limits on the number of refugees who could be sponsored from within the broader resettlement scheme, the United Kingdom established the most ambitious sponsorship initiative since the one Canada introduced forty years ago.

The UK sponsorship program relies entirely on the same legislative architecture that underpins its broader resettlement program: the only statutory reference to the community sponsorship scheme is a ministerial arrangement under the Equality Act, 2010, a technical inclusion that addresses the fact that the program focuses only on Syrian nationals and individuals affected by the Syrian conflict. 97 Otherwise, the formal legal framework enabling resettlement is silent on the introduction of community sponsorship.

\section{Regulations and Program Administration}

Details of the UK community sponsorship scheme are delineated through policy instructions, guidelines, and forms produced by the un Home Office. $9^{8}$ Collectively, these documents establish that citizens and community groups chosen as sponsors have primary responsibility for welcoming and integrating UNHCR-referred refugees to their local neighbourhoods. 99 Prospective sponsors must partner with registered charities or community interest companies, but these organizations are not required to have expertise in working with refugees and do not lead the process-thus preserving the core of the sponsorship model. ${ }^{100}$ Sponsors must also obtain written approval of the local authority in the sponsored family's future place of residence; ${ }^{101}$ demonstrate financial capacity to sponsor; ${ }^{102}$ and provide a detailed settlement plan that illustrates how they will deliver on their responsibilities, including securing housing for two years. ${ }^{103}$ After the uk Home Office provisionally approves a sponsor's application, a formal agreement is signed, ${ }^{104}$ and the sponsors must attend a training workshop before being authorized to resettle a family. ${ }^{105}$ Once authorized to sponsor, the uk Home Office works with the sponsors and local authority to allocate a suitable refugee family to each specific group. ${ }^{106}$

The UK community sponsorship scheme has inspired hundreds of local neighbourhoods to welcome refugees, and millions of pounds of public and private sector funding have been invested to develop capacity to recruit, vet, and support sponsorship groups and to evolve the policy model. ${ }^{107}$ This has resulted in significant sponsorship-specific infrastructure at the government and community level, ${ }^{108}$ and 
the program has become an entrenched part of the United Kingdom's resettlement landscape, with its own unique and sustainable ecosystem.

As a result of recent success in the United Kingdom, many countries considering their own sponsorship programs are interested in learning from the UK experience. This makes the absence of any dedicated legal architecture to support the UK sponsorship scheme noteworthy: unlike the Canadian program, which was introduced by a specific statutory reference, the robust uk program was enabled exclusively through a high-level political statement and detailed administrative processes. However, the program is part of a well-established overall resettlement program, and some of the state-level operations associated with that broader program-including the overseas refugee referral mechanism-have been largely retained. This means that the focus of the new sponsorship scheme has been exclusively on transitioning the modality for delivering post-arrival reception and support.

Our next case study, New Zealand, also introduced sponsorship within a well-established resettlement program. However, New Zealand relied on the combination of existing legal architecture and a robust Cabinet document to pilot both a new community-based reception program and new refugee referral criteria.

\section{New Zealand}

\section{Enabling Legislation and Orders}

New Zealand acceded to the Refugee Convention on 30 June 1960 and has a long history of welcoming newcomers fleeing persecution. ${ }^{109}$ It has been resettling UNHCR-referred refugees since the early 1980 s and operating its formal Refugee Quota Programme since 1987.110

New Zealand's 1987 Immigration Act ${ }^{111}$ introduced an extensive framework for refugee protection. The Immigration Act, $2009^{112}$ built on this framework and explicitly authorized resettlement. ${ }^{113}$ The 2009 Act also gave the minister a broad mandate to certify immigration instructions relating to, inter alia, residence class visas, ${ }^{114}$ and "any general or specific objective of immigration policy." 115 These Immigration Instructions set out the criteria for granting visas and permitting entry into the country, and provided the legal basis for a resettlement program. ${ }^{116}$ Between 2003 and 2018, New Zealand resettled over 10,200 refugees through its state-led Refugee Quota Programme. ${ }^{117}$

In June 2016 the New Zealand Cabinet agreed to increase its annual resettlement quota from 750 to 1,000 UNHCRreferred refugees" 118 and to pilot "a community organisation refugee sponsorship category ... as a new form of admission." 119 A Cabinet background paper on the community organization refugee sponsorship category (published on 30 August 2017) informed this decision; proposing that the sponsorship program would be distinct from the Refugee Quota Programme and would form a new "part of New Zealand's broader refugee and humanitarian programme."120 In September 2018, New Zealand announced that it would also increase its core annual quota by an additional 500 refugees per year, beginning in July 2019. ${ }^{121}$

Many specifics of New Zealand's pilot sponsorship program were laid out in the NZ Cabinet Minute of Decision (9 August 2017). ${ }^{122}$ In particular, individuals selected for the Community Organization Refugee Sponsorship Category needed to be recognized as refugees by the UNHCR; to possess a basic facility with English and a minimum of three years' work experience (or a qualification requiring a minimum of two years' tertiary study); and be between eighteen and forty-five years of age. ${ }^{123}$ Sponsors under the program needed to be registered legal entities; to have demonstrated experience working with refugees or other vulnerable people (although they did not need not be professional resettlement agencies); to possess financial and settlement capacity to support the sponsored refugees; and be willing to enter into an outcomes agreement with Immigration New Zealand for the provision of their settlement and integration responsibilities. ${ }^{124}$ Refugees resettled through the pilot community sponsorship program were to be granted permanent resident visas. ${ }^{125}$

The New Zealand Cabinet also agreed that sponsoring community organizations could either nominate refugees eligible for the sponsorship program or be matched to refugees referred to New Zealand by the UNHCR. ${ }^{126}$ The addition of new eligibility criteria and the option of sponsor-naming represented major Cabinet-directed variations to New Zealand's traditional resettlement program, and it is noteworthy that introducing these changes did not require legislative amendment. Instead, the very general nature of the existing statutory framework-focusing on visa criteria rather than the specifics of a particular resettlement stream-was deemed to provide the requisite legal authority for the pilot to be introduced and operationalized.

\section{Regulation and Program Administration}

New Zealand's 2009 Act is complemented by a series of regulations, ${ }^{127}$ and by the Department of Immigration's "Operational Manual." Amongst other things, the "Operational Manual" sets out specific details for the Refugee Quota Programme, including its objectives and eligibility requirements. ${ }^{128}$ It also establishes the requirement that resettled refugees receive an orientation at the Mangere Refugee Resettlement Centre ${ }^{129}$ - a component that was retained in the community sponsorship scheme. ${ }^{130}$ The Cabinet decision that gave rise to New Zealand's community sponsorship program was also implemented through the "Operational 
Manual." ${ }^{131}$ In addition to repeating the specific program requirements mandated by the original Cabinet decision, the "Operational Manual" also established the detailed process through which both sponsor groups and eligible refugees could apply to participate in New Zealand's pilot program. ${ }^{132}$

On 13 October 2017 the Ministry of Business, Innovation and Employment issued a request for applications from community organizations interested in becoming community sponsors under the new sponsorship stream. ${ }^{133}$ Interested organizations needed to establish that they met the requirements for sponsorship and were willing to sign a formal deed of agreement ${ }^{134}$ with the government of New Zealand guaranteeing that they would provide the required settlement responsibilities. ${ }^{135}$ According to the deed, approved community sponsors were solely responsible for fulfilling and could not subcontract to any other entity without first obtaining the written permission of the ministry. ${ }^{136}$ The four community-based groups selected to participate in New Zealand's community sponsorship pilot were announced in January $2018,{ }^{137}$ and it is noteworthy that none were professional refugee resettlement agencies. The first sponsored refugees arrived in New Zealand in July 2018. ${ }^{138}$

The government of New Zealand is reviewing its pilot program and considering whether to continue with a more permanent commitment to refugee sponsorship. In anticipation of this review, two distinct stakeholder groups-the Core Community Partnership and Amnesty Internationaleach presented proposals to the government urging, inter alia, that the community sponsorship program be made permanent; that funding be provided for a community-based "catalyst entity" to provide future sponsors with support; and that non-humanitarian criteria for refugee selection be reviewed. ${ }^{139}$ Amnesty International also presented a petition with over 10,000 signatures, encouraging New Zealand to continue the program. ${ }^{140}$ The New Zealand immigration minister responded publicly to this petition by noting that it was "heartening to see so many signatures from people in New Zealand saying they warmly support [the community sponsorship] program and encouraging the Government to go beyond the pilot." 141

Like the United Kingdom, New Zealand introduced its community sponsorship program by using the legal framework of its existing refugee resettlement scheme, rather than introducing any new statutory provisions. However, the New Zealand Cabinet both authorized the new program and provided significant direction on its parameters. This is different from all other countries, where detailed policy parameters for sponsorship programs were developed under delegated regulatory or administrative authority.

It is also noteworthy that, while New Zealand, Canada, and Argentina (described below) have all experimented with allowing sponsorship groups to support either a UNHCRreferred refugee or a sponsor-referred refugee (with some specific restrictions in each case), only Canada has introduced legislation that has formally recognized distinct referral mechanisms. In the other examples, the formal legislative instruments are silent on referral methodology.

Our next case study examines a newer resettlement country, Argentina, and explains how administrative processes created a resettlement program delivered exclusively through a sponsorship model.

\section{Argentina}

\section{Enabling Legislation and Orders}

Argentina ratified the Refugee Convention on 15 November $1961^{142}$ and has a long history of welcoming newcomers through its asylum system. ${ }^{143}$ However, the country's approach to resettlement has been noticeably iterative: in 1979 and 1980 its first formalized resettlement program focused on 300 refugees from Southeast Asia, ${ }^{144}$ and in 2005 it participated in the regional Solidarity Resettlement Program to resettle Colombian refugees. ${ }^{145}$ The creation of this second resettlement initiative corresponded with a broader overall restructuring of the country's formal legal architecture relating to refugees and immigrants, resulting first in introduction of the Migration Law ${ }^{146}$ in 2004, and then in the enactment of the General Law of Recognition and Protection of Refugees in 2006. ${ }^{147}$ Neither of these instruments specifically references either resettlement or sponsorship, but the Migration Law provides the legal basis for an individual's admission to, permission to stay in, or removal from Argentina and also enables humanitarian admissions using temporary status visas. ${ }^{148}$ Individuals resettled to Argentina with humanitarian visas may petition for refugee status once they arrive in the country. ${ }^{149}$

Argentina's most recent resettlement commitment has focused on Syrian refugees, and operates under the combined authority of the humanitarian visa regime set out in the Migration Law and two presidential decrees. ${ }^{150}$ The first presidential decree was issued in 2010 and sets out more detailed parameters for implementing the Migration Law, including its humanitarian provisions. ${ }^{151}$ The 2010 presidential decree also established the National Directorate for Migration as the agency responsible for implementing and enforcing the Migration Law and for creating associated regulations. ${ }^{152}$ Importantly, the 2010 presidential decree also delegated authority to Argentine consulates abroad to issue entry permits and visas, including humanitarian visas. ${ }^{153}$

A second presidential decree was issued in September 2016, shortly after Argentina's president announced at a UN summit that the country would resettle 3,00o Syrian refugees. The 2016 decree established a National Cabinet for the Syria 
Program to coordinate efforts of the ministries ${ }^{154}$ involved in the integration of refugees. 155 It also stipulated that the National Directorate for Migration would coordinate an inter-institutional working group to implement the national Cabinet's instructions and provide recommendations to the national Cabinet. ${ }^{156}$ The result was that two key coordinating bodies for the Syrian Resettlement Program were established through the 2010 and 2016 presidential decrees.

Further contours of Argentina's current resettlement commitment-the Special Humanitarian Visa Program for Foreigners Affected by the Syrian Conflict (Syria Program) are delineated in a regulatory scheme established by the National Directorate for Migration pursuant to its authority under the Migration Act and the 2010 presidential decree. As we explain below, Argentina's entire commitment to resettle Syrian refugees was designed to function as a national community sponsorship program. ${ }^{157}$

\section{Regulations and Program Administration}

In response to international appeals for more states to resettle Syrian refugees, Argentina's National Directorate for Migration created an administrative provision ${ }^{158}$ on 14 October 2014 (First Syria Program Provision), which established the country's Syria Program. The First Syria Program Provision introduced the initial iteration of the country's community sponsorship program by relying on the humanitarian admissions section of the Migration Law ${ }^{159}$ to enable Argentinian relatives of Syrian and Palestinian refugees to sponsor their family members' resettlement. Under this original program, Argentinian relatives (termed "callers" [llamantes]) needed to provide a letter of invitation attesting to their kinship bonds with the sponsored refugee; ${ }^{160}$ proof of identity; ${ }^{161}$ and proof of domicile. ${ }^{162}$ In 2014 and 2015 over 200 sponsorship applications were submitted under this original Syria Program, and the basic operational framework for Argentina's first community sponsorship program was formally established.

Momentum for Argentina's Syria Program was renewed in September 2016 when the country pledged to resettle 3,000 Syrian refugees. ${ }^{163}$ Responding to this commitment, the National Directorate for Migration issued a second provision $^{164}$ (Second Syria Program Provision), which updates the 2014 Syria Program by broadening the eligibility criteria for sponsors to include not only groups of individuals ("callers") 165 but also sponsoring organizations referred to as "requesters" (requirentes). The revised program allows both callers and requesters to initiate the humanitarian admission of individuals affected by the Syrian conflict by presenting a letter of invitation explicitly assuming a one-year commitment to provide accommodation and other integration support. ${ }^{166}$ Callers are also given the option of submitting a letter of endorsement from an organization, guaranteeing that callers will fulfil their commitments, ${ }^{167}$ and meaning that requestors may sponsor refugees directly or act as guarantors for callers. ${ }^{168}$ Significantly, the Second Syria Program Provision removes the requirement of familial ties between the sponsors and the sponsored refugees, ${ }^{169}$ enabling the introduction of a UNHCR referral mechanism. ${ }^{170}$

Argentina's Second Syria Program Provision also enables the National Directorate for Migration to implement mechanisms to collaborate with, and support, callers and requesters with the integration process. ${ }^{171}$ This function is implemented by the inter-institutional Working Group coordinated by the National Directorate for Migration, which-by virtue of the 2016 presidential decree-also receives instructions from the national Cabinet for the Syria Program. ${ }^{172}$ Successful implementation of Argentina's Syria Program and growth of its overall resettlement infrastructure is also supported by the UNHCR's Emerging Countries Joint Support Mechanism ${ }^{173}$ and by a 2018 investment by the European Union. ${ }^{174}$ As of July 2018, Argentinian callers and requesters had sponsored more than 400 refugees. ${ }^{175}$

As we have seen, Argentina relied on broad statutory provisions and two presidential decrees to authorize the issuance of humanitarian visas and create important infrastructure for resettlement, including the establishment of two key coordinating bodies. Critically, Argentina is the only country under examination that plans to deliver its entire resettlement program via community sponsorship. ${ }^{176}$ As with other examples, the details of this model were established and operationalized at the administrative level, but Argentina is unique, both in relation to its degree of reliance on sponsorship and the fact that the model is neither mentioned in statutory instruments nor referenced explicitly by orders from the executive branch. The cumulative effect is that Argentina used entirely administrative processes to translate its broad humanitarian visa regime and a political commitment to support Syrian refugees into a well-delineated community sponsorship-based resettlement scheme. ${ }^{177}$

Our final case study examines the United States-a large resettlement country that does not have a national community sponsorship program. Nevertheless, a number of American civil society organizations have recognized the potential of sponsorship and built their own mini infrastructure within the country's broader overall resettlement scheme.

\section{United States}

\section{Resettlement Framework}

The United States is not a party to the Refugee Convention but did accede to its additional protocol on 1 November 1968 and is thus bound by articles $2-34$ of the convention and to the core principle of non-refoulement. ${ }^{178}$ The country has a long history of accepting refugees from all over the world ${ }^{179}$ 
and in 1980 created the us Refugee Admission Program (USRAP) through the enactment of the Refugee Act of $1980 . .^{180}$ Introduction of the USRAP created a "standardized system for identifying, vetting, and resettling" refugees ${ }^{181}$ and, since then, the United States has resettled more refugees than any other country: annual admissions peaked between 1990 and 1995 with an average of 112,000 refugees resettled annually, and remained high into the 2010s, with 78,761 refugees resettled in 2016. ${ }^{182}$ These numbers dropped precipitously to 24,559 in $2017^{183}$ and to 15,784 in $2018^{184}$ under a new US administration. Between 2003 and 2018 the United States resettled over 640,000 refugees from all over the world. ${ }^{185}$

The backbone of us immigration and refugee policy is the Immigration and Nationality Act (INA), a wide-ranging statutory regime introduced in $1985 .{ }^{186}$ The INA continues the us resettlement program and gives the president absolute discretion to set the country's annual refugee resettlement quota, taking into consideration both humanitarian concerns and the national interest. ${ }^{187}$ The scheme specifies that, once the president establishes the annual quota, the United States must work with the UNHCR, other specially trained NGOs, and its embassies abroad to receive referrals of individuals eligible for its refugee admissions program. ${ }^{188}$ Resettled refugees are admitted to the United States with refugee status. After one year of residency, they may request permanent resident status, and after five years they are eligible to apply for us citizenship. ${ }^{189}$

The INA also established the Office of Refugee Resettlement (ORR) within the Department of Health and Human Services. The ORR is tasked with funding and administering the domestic implementation of the us resettlement program. ${ }^{190}$ Specifically, the INA gives the ORR authority to work with stakeholders to develop policies on resettlement ${ }^{191}$ and to provide grants and contracts to "public or private nonprofit agencies for initial resettlement ... of refugees in the United States." ${ }^{192}$ To deliver on its resettlement mandate, the ORR partners with nine professional resettlement agencies, ${ }^{193}$ each of which is responsible for ensuring that a refugee's settlement needs are met, ${ }^{194}$ including housing, furnishings, food, clothing, and facilitated access to community and state-provided services. ${ }^{195}$

The ORR's nine resettlement partners in turn subcontract these responsibilities to hundreds of local service providers all across the United States. These organizations welcome and integrate refugees under authority delegated by the ORR. ${ }^{196}$ There is wide variance in how these local partners operate, but the majority use a combination of professional case workers and volunteers to provide support.

Certain us organizations have, however, been inspired by the community sponsorship model and have chosen to further delegate core integration and decision-making responsibilities to highly empowered groups of sponsors. ${ }^{197}$ This has the effect of creating de facto community sponsorship models within certain communities. Since the Us government did not create or formally acknowledge these programs, ${ }^{198}$ and since the refugee agencies retain ultimate oversight and responsibility for the groups, we term this model "co-sponsorship."

\section{Community-Level Co-sponsorship}

One example of a robust and successful community cosponsorship program was introduced by Integrated Refugee \& Immigrant Services (IRIS) in Connecticut-a local affiliate of two of the nine US resettlement agencies. ${ }^{199}$ Under the IRIS co-sponsorship model, community groups of at least ten people are empowered to take primary responsibility for welcoming and integrating resettled refugees into their communities. ${ }^{200}$ Once these groups demonstrate to IRIS that they are prepared to welcome a refugee family, they must sign a formal agreement pledging to fulfill their responsibilities towards the resettled refugees. ${ }^{201}$ Responsibilities include fundraising to provide housing and basic necessities; welcoming the family on arrival; providing orientation and transportation assistance; assisting in connecting the family with health, education, and other services and benefits; helping the family manage its resources and secure employment; ${ }^{202}$ and offering overall logistical and emotional support.

IRIS provides guidance and training to co-sponsorship groups as they prepare to meet their responsibilities, and subsequently provides light-touch support to sponsors as needed. It also delivers federally required case management for the refugee family through a number of check-ins during the initial resettlement period. ${ }^{203}$ However, the agency does not direct the activities of the co-sponsors, who become the key decision-makers and implementers of all aspects of the settlement process. This represents a radical shift from the more traditional, highly professionalized us resettlement model. In 2016 one-third of the 530 refugees referred to IRIS were settled by community co-sponsorship groups, ${ }^{204}$ allowing the agency to increase its overall capacity, welcome more newcomers to its area, and significantly grow the number of individual citizens engaging in significant ways with newly arrived refugees. ${ }^{205}$ While the United States does not have a formal sponsorship program, the IRIs program demonstrates that key components of sponsorship can be implemented not only within existing legal frameworks, but also within traditional operational models.

\section{Conclusion}

Community sponsorship programs have the potential to be truly transformative. Countries seeking new ways to 
contribute to global refugee protection, while simultaneously improving integration outcomes and benefiting their own local communities, are examining Canada's long history with sponsorship and considering how similar models might be introduced in their own domestic contexts. Our work with the GRSI has shown us that one of the first steps for any country considering a community sponsorship program is an examination of what laws, regulations, and policies are necessary to make it operational. The case studies presented in this article illustrate some of the varying approaches that have been taken in this regard.

Canada is the only country to have embedded sponsorship into its principal immigration and refugee statute simultaneously with the introduction of a nascent resettlement program. The United Kingdom and Argentina provide interesting contrasts to this approach. Both countries developed and operationalized sponsorship programs subsequent to high-level political announcements. In Argentina the commitment was a general one to resettle Syrian refugees, while in the United Kingdom it was a specific reference to the introduction of a community-led sponsorship program. After these announcements, both countries introduced their programs without any new supporting legislation: Argentina by creating a new regulatory framework under the broad authority of its general immigration law; and the United Kingdom by leveraging the administrative frameworks associated with two pre-existing resettlement programs. It is also noteworthy that, while both of these newer sponsorship programs are limited to refugees affected by the Syrian conflict, the specific regulatory infrastructure enabling the UK program does not reflect this restriction, ${ }^{206}$ while Argentina's does. This is consistent with Argentina's iterative approach to resettlement and may mean that additional political directives or legal authority would be needed for the country to retain its sponsorship program as a longer-term feature of its overall refugee policy.

Like the United Kingdom, New Zealand introduced its community sponsorship program into a well-established resettlement framework. However, while both programs rely on existing resettlement infrastructure and were introduced without legislative amendment, a significant amount of programmatic detail for the New Zealand program was included in the authorizing Cabinet documents. As a result, any subsequent policy changes to New Zealand's program will presumably require renewed parliamentary approval. It is of course noteworthy that, at the time of writing, New Zealand's sponsorship program was limited to a small-scale pilot initiative; it is possible that a future, longer-term commitment will be embedded into the country's legal infrastructure in a different way.
Finally, the development of co-sponsorship programs in the United States illustrates how the core elements of sponsorship can be implemented by motivated and creative civil society actors willing to deliberately de-professionalize their approach to refugee resettlement. The successful program at IRIS is a particularly strong example of what can be achieved in the absence of any formal adjustments to the national infrastructure. Of course, these initiatives rely on an existing resettlement pathway that is legally and administratively embedded, and in this way the United States most closely resembles the UK example.

While each of these situations is unique, our overall conclusion is that community sponsorship programs do not require significant, dedicated legislative infrastructure. In fact, Canada is the only country to have introduced a statutory provision explicitly authorizing community engagement in resettling refugees, and that provision is extremely broad. More frequently, sponsorship programs have been introduced through a combination of political will and administrative creativity.

For the many countries considering new sponsorship programs, this is good news: while they may need to carefully consider the political, policy, and operational realities of these systems, they likely do not need to undertake widescale legislative reform. As true believers in the power of sponsorship to transform the lives of both newcomers and the communities that welcome them, we hope this means that more programs will be introduced in the near term. Indeed, with global capacity shrinking at an alarming rate and the world desperately in need of creative solutions, the future of refugee resettlement may depend on it.

\section{Notes}

1 We owe thanks for research and editorial support to Eliza Bateman, Christina Clemente, Rebecca Dickey, Mari Galloway, Jacintha Gedeon, Marcos Gomez, Shannon Kristjanson, Meghan Steenhoek, and Lyndsay Scovil. All errors or omissions are of course our own.

2 Via an enactment of a law by the legislative branch of a government.

3 Merriam-Webster OnLine, s.v. "regulation," accessed 30 January 2019, https://www.merriam-webster.com/dictionary /regulation. For the purposes of this article, we are using the following definitions of regulation from the MerriamWebster Dictionary: "an authoritative rule dealing with details or procedure" and "a rule or order issued by an executive authority or regulatory agency of a government and having the force of law."

4 Merriam-Webster OnLine, s.v. "policy," accessed 30 January 2019, https://www.merriam-webster.com/dictionary/ policy?src=search-dict-box. For the purposes of this article, 
we are using the following definition of policy from the Merriam-Webster Dictionary: "an overall plan, principle, or guideline; especially: one formulated outside of the judiciary."

5 Recent data suggest that refugees privately sponsored to Canada find employment within their first five years of settlement at higher rates (7o per cent) and earn higher incomes than their government-resettled counterparts ( 57 per cent). Penetration into the labour market levels out between these two groups after approximately ten years. Twenty years after arrival, privately sponsored refugees have a median income better than other Canadians. Median income for government-resettled refugees after twenty years is just below that of other Canadians. Note that these studies do not disaggregate between UNHCR-referred sponsored refugees and sponsor-referred refugees. The latter may have family or other ties to Canada and may not possess the same vulnerabilities as UNHCR-referred refugees, who have additional integration challenges. See Statistics Canada, "Immigrant Income by World Area, Canada," https://www15o.statcan. gc.ca/tı/tbl1/en/tv.action?pid=4310003401; Government of Canada, "Evaluation of the Resettlement Programs (GAR, PSR, BVOR and RAP)," 7 July 2016, https://www.canada.ca/ en/immigration-refugees-citizenship/corporate/reportsstatistics/evaluations/resettlement-programs.html.

6 A 2018 report published by the Environics Institute for Survey Research found that in 2015/16 close to two million adult Canadians were involved directly in community sponsorship of Syrian refugees: Environics Institute for Survey Research, Canada's World Survey 2018: Final Report (Toronto: Environics Institute for Survey Research, 2018), 35, https://3meaon49d536386oyn4ri4go-wpengine.netdna-ssl .com/wp-content/uploads/2018/o4/Canada-World-Survey2018.pdf. In September 2015 much of the federal election focused on the respective parties' commitments to welcoming Syrian refugees, including through community sponsorship: Mark Kennedy, "Where the Parties Stand on Syrian refugees," Ottawa Citizen, 4 September 2015, https:// ottawacitizen.com/news/politics/where-the-parties-standon-syrian-refugees. Since the election, opposition parties have continued to urge the Canadian government to expand and remove barriers to the community sponsorship program. See, e.g., Michelle Rempel, "Urgent Measures Required to Assist Yazidi Victims of Genocide," Conservative Party of Canada, 21 July 2016, https://www.conservative .ca/urgent-measures-required-to-assist-yazidi-victims-ofgenocide/; National Post, "Opposition Calls for Liberals to Be True to Refugee Rhetoric, Change System," 20 June 2017, https://nationalpost.com/pmn/news-pmn/canada-newspmn/opposition-mps-press-liberals-to-be-true-to-refugeerhetoric-change-system.

7 See, e.g., ввC News, "Migrant Crisis: Photo of Drowned Boy Sparks Outcry," 3 September 2015, https://www.bbc. com/news/world-europe-34133210; ввС News, "Migrant Crisis: Nine Key Moments from the Last Year," 7 September 2015, https://www.bbc.com/news/world-europe-34173972;
Gregor Aisch, Sarah Almukhtar, Josh Keller, and Wilson Andrews, "The Scale of the Migrant Crisis, from 160 to Millions," New York Times, 22 September 2015, https://www .nytimes.com/interactive/2015/o9/10/world/europe/scaleof-migrant-crisis-in-europe.html; Economist, "Strangers in Strange Lands," 12 September 2015, https://www.economist .com/briefing/2015/o9/12/strangers-in-strange-lands.

8 See, e.g., Joel Gunter, "Migrant Crisis: The Volunteers Stepping In to Help," ввс News, 3 September 2015, https://www .bbc.com/news/world-europe-34130639; Emma GrahamHarrison, Patrick Kingsley, and Tracy McVeigh, "Cheering German Crowds Greet Refugees after Long Trek from Budapest to Munich," Guardian, 5 September 2015, https:// www.theguardian.com/world/2015/sep/05/refugee-crisiswarm-welcome-for-people-bussed-from-budapest; Eliza Goroya, Khairunissa Dhala, and Lorna Hayes, "Volunteers Help Refugees Survive while Europe's Leaders Still Search for Solutions," Amnesty International, 21 September 2015, https://www.amnesty.org/en/latest/campaigns/2015/o9/ volunteers-help-refugees-survive-while-europes-leadersstill-search-for-solutions/; Emily Anne Epstein, "Welcomed to Europe," Atlantic, 22 November 2015, https://www .theatlantic.com/photo/2015/11/the-arms-outstretched/ $416916 /$.

9 In November 2015 a newly elected Canadian government sought to fulfill a campaign commitment to bring 25,000 Syrian refugees to Canada before the end of 2015. It ultimately succeeded in landing over 26,000 Syrian refugees by the end of February 2016, with over 11,000 of these being privately sponsored or sponsored through Canada's Blended Visa Office-Referred Program. See Immigration, Refugees and Citizenship Canada, "Canada's Syrian Commitments," last modified 26 July 2017, https://www.canada. $\mathrm{ca} /$ en/immigration-refugees-citizenship/services/refugees/ welcome-syrian-refugees/canada-commitment.html.

10 A total of 40,081 Syrian refugees were resettled to Canada by the end of 2016, including 18,205 who were privately sponsored or sponsored through Canada's Blended Visa OfficeReferred Program to over 400 Canadian communities from coast to coast to coast. See Immigration, Refugees and Citizenship Canada, “\#WelcomeRefugees: Key Figures," https:// www.canada.ca/en/immigration-refugees-citizenship/ services/refugees/welcome-syrian-refugees/key-figures .html\#popup1.

11 An additional seven million know someone who sponsored during this period: Environics Institute for Survey Research, Canada's World Survey 2018: Final Report.

12 UNHCR, "Canada, UNHCR and Open Society Foundations Seek to Increase Refugee Resettlement through Private Sponsorship," news release, 19 September 2016, http://www .unhcr.org/news/press/2016/9/57eoe2784/canadaunhcr-open-society-foundations-seek-increase-refugeeresettlement.html.

13 Global Refugee Sponsorship Initiative, "About GRSI," http:// refugeesponsorship.org/who-we-are. See also UNHCR, 
“Global Refugee Sponsorship Initiative Promotes Canada's Private Refugee Sponsorship Model," 16 December 2016, http://www.unhcr.org/news/press/2016/12/58539e524/ global-refugee-sponsorship-initiative-promotes-canadasprivate-refugee.html. The launch event brought together over ninety civil society and government official participants from nine countries. The GRSI works toward these goals by providing tailored, direct assistance to government officials and community leaders in countries around the world interested in learning about, designing, and implementing community sponsorship programs. Support activities, inter alia, technical support in policy development, infrastructure planning, development of materials such as forms and guides, evaluation design, facilitating peer-to-peer learning, and providing training to sponsors.

14 FrankGiustra, "It Will TakeMore Than GovernmentstoSolve the Global Refugee Crisis," Globe and Mail, 30 April 2018, https://www.theglobeandmail.com/business/commentary/ article-it-will-take-more-than-governments-to-solve-theglobal-refugee-crisis/.

15 The European Commission has encouraged EU member states to establish sponsorship schemes and has mandated the European Asylum Support Office to coordinate a pilot sponsorship project. See European Commission, "State of the Union 2017: Commission Presents Next Steps towards a Stronger, More Effective and Fairer EU Migration and Asylum Policy," news release, 27 September 2017, http:// europa.eu/rapid/press-release_IP-17-3406_en.htm.

16 UN General Assembly, Report of the United Nations High Commissioner for Refugees-Part II: Global Compact on Refugees, 73rd Sess, Un Doc A/7312 (Part II), 2 August 2018, para 95, https://www.unhcr.org/excom/ unhcrannual/5ba3a5d 44/report-united-nations-highcommissioner-refugees-part-ii-global-compact.html.

17 Global Refugee Sponsorship Initiative, "Joint Statement: Ministers from Canada, the United Kingdom, Ireland, Argentina, Spain and New Zealand Underline Their Support for Community-Based Refugee Sponsorship in Advance of the 2018 United Nations General Assembly and Agreement on the Global Compacts on Refugees," news release, 16 July 2018, http://refugeesponsorship.org/_ uploads/5b4cao1e5c883.pdf.

18 European Commission, Study on the Feasibility and Added Value of Sponsorship Schemes as a Possible Pathway to Safe Channels for Admission to the EU, Including Resettlement: Final Report (Luxembourg: Publication Office of the European Union, 2018), 4.

19 Jennifer Bond, "Conceptualizing Sponsorship" (forthcoming).

20 Community-based refugee sponsors take on financial and settlement responsibilities for a designated period (usually one to two years). These include initial reception and welcome; providing housing, furniture, and furnishings; orienting sponsored refugees to their communities and helping them access necessary public services (e.g., health, education); assisting in securing employment; supporting language training; and providing emotional and moral support.

21 Some programs allow sponsors themselves to nominate refugees for sponsorship, while others rely on UNHCR or other agencies to refer eligible refugees, who are then matched to approved sponsors. Criteria for sponsor and refugee eligibility may differ. The manner in and degree to which responsibilities are divided between the sponsors, government, and other service providers depends on the broader welfare context of a particular country.

22 European Resettlement Network, Private Sponsorship in Europe: Expanding Complementary Pathways for Refugee Resettlement (Brussels: ICMC Europe, 2017), 11.

23 Lester M. Salamon, "The Resilient Sector: The State of the Nonprofit America," in The State of Nonprofit America, ed. Lester M. Salamon (Washington, DC: Brookings Institution, 2002), 20. See also Emilia E. Martinez-Brawley and Paz M-B Zorita, "Immigration and Human Services: The Perils of Professionalization," Families in Society: The Journal of Contemporary Human Services 92, no. 2 (2011): 133.

24 While there is no settled, universally applicable definition of resettlement, most definitions contain two key elements: (1) refugees moving from a country of asylum; (2) to a country that has voluntarily agreed to provide them with protection. The most frequently used definition of resettlement, particularly by governments and refugee organizations, is that established by UNHCR: "the selection and transfer of refugees from a State in which they have sought protection to a third State which has agreed to admit them - as refugees - with permanent status." See UNHCR Resettlement Handbook (Geneva: UNHCR, 2011), 3, http://www.unhcr.org/46f7coee2.pdf. The European Union draws a distinction between resettlement and relocation to reflect its regional governance structure: European Commission, "Resettlement and Relocation," https://ec.europa .eu/home-affairs/sites/homeaffairs/files/what-we-do/ policies/european-agenda-migration/backgroundinformation/docs/relocation_and_resettlement_factsheet en.pdf. There is greater variance in definition among academics, with some using similar definitions to that of UNHCR, such as Lyra Jakuleviciene and Mantas Bileisis, "EU Refugee Resettlement: Key Challenges of Expanding the Practice into New Member States," Baltic Journal of Law \& Politics 9, no. 1 (2016): 93; some adding to it, such as Kristin Bergtora Sandvik, "A Legal History: The Emergence of the African Resettlement Candidate in International Refugee Management," International Journal of Refugee Law 22, no. 1 (2010): 20-47; some combining resettlement with integration, such as Gillian Morantz, Cécile Rousseau, Anna Banerji, Carolina Martin, and Jody Heymann, "Resettlement Challenges Faced by Refugee Claimant Families in Montreal: Lack of Access to Child Care," Child \& Family Social Work 18, no. 3 (2013): 318. 
25 Convention relating to the Status of Refugees, 28 July 1951, 189 UNTS 137 at preamble (entered into force 22 April 1954), https://treaties.un.org/doc/Treaties/1954/04/19540422\%20 oo-23\%2oAM/Ch_V_2p.pdf. The Refugee Convention defines refugee in Article $1 \mathrm{~A}(2)$ as any person who "owing to a well-founded fear of being persecuted for reasons of race, religion, nationality, membership of a particular social group or political opinion, is outside the country of his nationality and is unable or, owing to such fear, is unwilling to avail himself of the protection of that country; or who, not having a nationality and being outside the country of his former habitual residence as a result of such events, is unable or, owing to such fear, unwilling to return to it." The Refugee Convention requires states to, inter alia, refrain from punishing refugees for their illegal entry or presence onto their territory for the purpose of making an asylum claim (Article 31); and refrain from returning refugees to a country where they would face a threat to their life or freedom on account of their race, religion, nationality, membership in a particular social group, or political opinion (the duty of non-refoulement in Article 33).

26 Refugee Convention, at preamble; un General Assembly, New York Declaration for Refugees and Migrants, resolution adopted by the General Assembly, 3 October 2016, A/ RES/71/1 para. 68; un General Assembly, Global Compact on Refugees, para 15. See also Global Compact on Refugees, paras. 90-3 referring to arrangement for "more equitable and predictable burden- and responsibility-sharing" and para. 95, which refers to responsibility sharing through community-based sponsorship.

27 UNHCR, UNHCR Projected Global Resettlement Needs 2019 (Geneva: UNHCR, 2018), 78-9, http://www.unhcr.org/ protection/resettlement/5b28a7df/projected-globalresettlement-needs-2019.html, which shows two tables documenting departures to resettlement countries from 2013 to 2017, and per capita resettlement per country of resettlement in 2017. For a detailed overview of the politics and power dynamics of global resettlement practices, see Adèle Garnier, Liliana Lyra Jubilut, and Kristin Bergtora Sandvik, eds., Refugee Resettlement: Power, Politics and Humanitarian Governance (New York: Berghahn Books, 2018).

28 It is important to distinguish community sponsorship from volunteering in support of refugees. "Although volunteers help professionals with important work, they are not ultimately responsible for the refugee's well-being. Sponsorship is special because ordinary citizens drive the process. While sponsors may sometimes contact outside organizations to access training and support, they are uniquely responsible for making key decisions and supporting the newcomer in every way." See Global Refugee Sponsorship Initiative video, How Communities Sponsor Refugees: Canada's Program, YouTube video, posted 23 April 2018, https:// youtu.be/KbdXZRbGxz8.
29 See, e.g., Justice and Peace, a Dutch NGo that has developed a program called Samen Hier, which "connects groups of five Dutch citizens or more to an individual newcomer or family to help status holders find their way in a new society." See Samen Hier, "Justice and Peace," https://www .justiceandpeace.nl/initiatives/samen-hier/.

30 See, e.g., "Refugees at Home," a "uk based charity aiming to connect those with spare room in their home with asylum seekers and refugees in need of accommodation": Refugees at Home, "FAQ," https://www.refugeesathome.org/faq/ index.html.

31 For Ireland and Germany's family reunification programs, see European Commission, Study on the Feasibility and Added Value of Sponsorship Schemes.

32 In Australia's Community Support Program, "sponsors" are primarily responsible for identifying and funding resettlement applications, while professional agencies-“Approved Proposing Organizations"- "link applicants with secure, reputable employment and community support [and] link entrants with other government services." See Australian Department of Home Affairs, "Community Support Program (CSP)," https:// immi.homeaffairs.gov.au/what-we-do/refugee-andhumanitarian-program/community-support-program/ approved-proposing-organisations.

33 See Humanitarian Corridors programs Belgium, France, and Italy: see European Commission, Feasibility Study.

34 UNHCR, "States Parties to the 1951 Convention relating to the Status of Refugees and the 1967 Protocol," 28 June 2011, http://www.unhcr.org/protection/basic/3b73bod63/statesparties-1951-convention-its-1967-protocol.html.

35 For a detailed description of the policy review and legislative drafting process, see Gerald E. Dirks, "A Policy within a Policy: The Identification and Admission of Refugees to Canada," Canadian Journal of Political Science 17, no. 2 (1984): 279. See also Freda Hawkins, Critical Years in Immigration: Canada and Australia Compared, 2nd ed. (Montreal and Kingston: McGill-Queen's University Press, 1991), 158.

36 The new legal framework explicitly recognized refugees as a distinct class of migrants and included a more transparent approach for overseas selection and resettlement: Hawkins, Critical Years in Immigration, 174-6; Michael Casasola, "The Indochinese Refugee Movement and the Subsequent Evolution of UNHCR Resettlement Selection Policies," Refuge 32, no. 2 (2016): 41.

37 Dirks, "Policy within a Policy," 280; Ninette Kelley and Michael J. Trebilcock, The Making of the Mosaic: A History of Canadian Immigration Policy (Toronto: University of Toronto Press, 2010), 404-5. It is noteworthy that some of these orders-in-council even permitted community-based sponsorship arrangements, such as the 2 June 1922 order for the admission of 21,000 Mennonites from the Soviet Union on the condition that Canadian Mennonite communities 
ensure they would be cared for, they would not become a burden to the public, and they would be settled on agricultural land. See William Janzen, "The 1979 MCC Canada Master Agreement for the Sponsorship of Refugees in Historical Perspective," Journal of Mennonite Studies 24 (2006): 212. At 212-13 Janzen also describes a second movement of Mennonite refugees from Europe after the Second World War under similar sponsorship arrangements. At 213-15 Janzen describes a number of other resettlement efforts that, although they were not fully sponsorships, had substantial involvement from community and church groups in the selection of refugees and their integration into Canadian society.

38 The Immigration Act, 1976 introduced admissibility criteria, as well as requirements for refugees to pass security, medical, and criminality screenings before being admitted to Canada. All immigrants-including refugees-were also required to demonstrate that they would be able to successfully settle in Canada, although the Act did allow for regulations to create exceptions in certain humanitarian situations: Immigration Act, 1976, SC 1977, C 52, s 19.

39 Immigration Act, 1976, sc 1977, c 52, ss 2, 9(4). Section 9(4) of the Immigration Act, 1976 enabled visa officers to "grant landing or entry" to Canada if satisfied the applicant to Canada satisfied the requirements of the Act. The Act defines landing as "lawful permission to come into Canada to establish permanent residence."

40 UNHCR Canada, "Refugee Resettlement Facts," https://www .unhcr.ca/wp-content/uploads/2017/o4/CanadianResettlement-Fact-Sheet-ENG-April-2017.pdf.

41 Immigration Act, 1976, s 115(1)(b).

42 Immigration Act, 1976, s 115(1)(b).

43 Immigration Act, 1976, s 115(1)(k.1).

44 Kelley and Trebilcock, Mosaic, 407.

45 Kelley and Trebilcock, Mosaic.

46 Kelley and Trebilcock, Mosaic.

47 On top of the existing 8,000 pledged, an additional 21,000 Indochinese refugees would be government-assisted and 21,000 would be privately sponsored: Kelley and Trebilcock, Mosaic, 407. The 50,000 quota was increased even further to 60,000 on 2 April 1980 after the Liberal party had returned to power. More than 7,000 private groups and organizations sponsored 34,000 Indochinese refugees in the late 1970s, outpacing government resettlement and giving birth to Canada's new and unique form of refugee resettlement: Hawkins, Critical Years in Immigration, 183-4.

48 Hawkins, Critical Years in Immigration, 183.

49 Kelley and Trebilcock, Mosaic, 408; Casasola, "Indochinese Refugee Movement," 45; Hawkins, Critical Years in Immigration, 183-4. The Canadian Immigration Historical Society provides a flow chart detailing how Canadian private sponsorship applications were processed from the first step of sponsors identifying the refugees they wished to sponsor, to the refugees' arrival in Canada. See Canadian
Immigration Historical Society, "Sponsorship System: Algorith\#2-March 1978," http://cihs-shic.ca/wp-content/ uploads/2015/03/Sponsorship-Chart-1978-corrected.pdf. However, the society notes that the "process was modified on May 1979 to factor in the new Destination Matching Centres that matched accepted refugees with potential sponsors in Canada who did not have a particular refugee in mind to support." For more details of the matching process, see Canadian Immigration Historical Society, "Historical Documents: The Indochinese Refugee Movement," http://cihs-shic.ca/indochina-historical-documents/.

50 Immigration Regulations, 1978, SOR/78-172.

51 See Hawkins, Critical Years in Immigration, 78-9, 175.

52 Immigration Regulations, 1978, Reg. 2: defined as "Convention refugee who has not become permanently resettled and is unlikely to be voluntarily repatriated or locally resettled."

53 Immigration Regulations, 1978, Reg. 7(2). These general requirements remain the same today, although they have been formalized into several types of sponsorship groups: Groups of Five, Community Sponsors, Sponsorship Agreement Holders, Constituent Groups, and Co-Sponsors. For more information, see Government of Canada, "2. Private Sponsorship of Refugees Program," s 2.3, accessed 24 January 2019, https://www.canada.ca/en/immigrationrefugees-citizenship/corporate/publications-manuals/ guide-private-sponsorship-refugees-program/section-2 .html\#a2.3.

54 Immigration Regulations, 1978, Reg. $7(2)$.

55 Immigration Regulations, 1978, Reg. 7(2)(e).

56 The other two were the Latin American Political Prisoners and Oppressed Persons class for refugees from, and the Eastern European Self-Exiled Persons class: see Kelley and Trebilcock, Mosaic, 406. See also Hawkins, Critical Years in Immigration, 78-9.

57 Janzen, “MCC Canada Master Agreement," 213-15; Casasola, "Indochinese Refugee Movement," 44; Barbara Treviranus and Michael Casasola, "Canada's Private Sponsorship of Refugees Program: A Practitioners Perspective of Its Past and Future," Journal of International Migration and Integration 4, no. 2 (2003): 177, 184.

58 Stephanie Dyck, "Advancing Private Refugee Sponsorship: Engaging and Resourcing MCC Manitoba's Constituency" (master's thesis, University of Victoria, 2016), 6, accessed 24 January 2019, https://dspace.library.uvic.ca/ bitstream/handle/1828/7777/Dyck_Stephanie_MA_2016 .pdf? sequence $=1 \&$ is Allowed $=y$.

59 The Master Agreement also delineated the Master Agreement Holders' and the government's respective roles and responsibilities, and how communications would flow between Master Agreement Holders, their congregations, local immigration offices, and overseas Embassies. By the end of 1980, 485 constituent groups of Canada's First Master Agreement Holder-the Mennonite Central Committee of 
Canada-brought approximately 4,000 refugees to Canada. Janzen, "MCC Canada Master Agreement," 212; Dyck, "Advancing Private Refugee Sponsorship," 6.

6o Janzen, "MCC Canada Master Agreement," 212; Casasola, "Indochinese Refugee Movement," 44-5.

61 Casasola, "Indochinese Refugee Movement," 44-5: "These organizations, initially mainly faith groups, serve as financial guarantors, enabling the organization and its constituent groups to apply to sponsor a refugee(s) without having to demonstrate the financial capability for each individual application as required of a Group of Five."

62 Janzen, "MCC Canada Master Agreement," 212.

63 Immigration and Refugee Protection Act, sC 2001, c 27.

64 Immigration and Refugee Protection Regulations, SOR/2002-227.

65 Immigration and Refugee Protection Act, s 13(1): "A Canadian citizen or permanent resident, or a group of Canadian citizens or permanent residents, a corporation incorporated under a law of Canada or of a province or an unincorporated organization or association under federal or provincial law-or any combination of them-may sponsor a foreign national, subject to the regulations."

66 Immigration and Refugee Protection Regulations, Reg. 138.

67 Immigration and Refugee Protection Regulations, Reg. 139.

68 Government of Canada, "2. Private Sponsorship of Refugees Program," s 2.3.

69 Canadian sponsors may name the specific refugees they wish to sponsor through Canada's Private Sponsorship of Refugees (PSR) program. They may also be matched to UNHCR-referred refugees in Canada's Blended Visa OfficeReferred Program. Sponsors may also be matched to UNHCR-referred and Government-Assisted Refugees with special needs through the Joint Assistance Sponsorship Program. For a description of these programs, see Immigration, Refugees and Citizenship Canada, "Guide to the Private Sponsorship of Refugees Program," https://www .canada.ca/en/immigration-refugees-citizenship/ corporate/publications-manuals/guide-privatesponsorship-refugees-program.html.

70 See Refugee Sponsorship Training Program, "LGBTI Refugee Sponsorship Pilot Project," http://www.rstp.ca/en/ special-initiatives/lgbti-refugee-sponsorship-pilot-project/.

71 See Immigration, Refugees and Citizenship Canada, Guide to the Private Sponsorship of Refugees Program, s 3.4, Urgent Protection Program, https://www.canada.ca/en/ immigration-refugees-citizenship/corporate/publicationsmanuals/guide-private-sponsorship-refugees-program/ section-3.html.

72 Immigration, Refugees and Citizenship Canada, Guide to the Private Sponsorship of Refugees Program, section 3.4; Immigration, Refugees and Citizenship Canada, "Procedure: Expedited Processing and Vulnerable Cases," https:// www.canada.ca/en/immigration-refugees-citizenship/ corporate/publications-manuals/operational-bulletins- manuals/refugee-protection/resettlement/processingprocedure-expedited-processing-vulnerable-cases.html.

73 World University Service Canada, a Sponsorship Agreement Holder, has developed its own infrastructure for the overseas selection of post-secondary refugee students, bringing them to Canada through the PSR program, and engaging oncampus student groups to welcome sponsored refugees not only to life in Canada, but to their new post-secondary educational environment. See World University Service Canada, "Student Refugee Program," https://srp.wusc.ca/.

74 Today, Canada's immigration and refugee law is governed by the Immigration and Refugee Protection Act, and its Immigration and Refugee Protection Regulations. Section 13(1) of the Act retains a central provision enabling sponsorship. It states, "A Canadian citizen or permanent resident, or a group of Canadian citizens or permanent residents, a corporation incorporated under a law of Canada or of a province or an unincorporated organization or association under federal or provincial law-or any combination of them-may sponsor a foreign national, subject to the regulations." The Regulations set out, inter alia, the eligibility criteria for sponsors (Reg. 138) and sponsored refugees (Reg. 139).

75 Ratification status of the Convention Relating to the Status of Refugees, 1-3. It also joined the Additional Protocol on 4 September 1968: UNHCR, "States Parties to the 1951 Convention," 4.

76 This consisted initially of two informal programs. Through the first, the UNHCR's Ten or More program, countries would commit to resettling ten or more refugees and their families annually: Government of the United Kingdom of Great Britain and Northern Ireland, UNHCR Resettlement Handbook, Country Chapter-uk," September 2007, https://www.refworld.org/pdfid/46f3a7ac2.pdf; Nadine ElEnany and Jeremy Bernhaut, KNOW RESET: Building Knowledge for a Concerted and Sustainable Approach to Refugee Resettlement in the EU and Its Member States-Country Profile-United Kingdom (San Domenico di Fiesole, Italy: European University Institute, Robert Schuman Centre for Advance Studies, 2013), http://www.know-reset.eu/ files/texts/o0170_20130919160801_knowresetcountryprofileunitedkingdom.pdf. The second, the Mandate Resettlement Scheme (MRS), was established in 1995 and applies to mandate refugees, defined as "persons who are recognized as refugees by UNHCR acting under the authority of its Statute and relevant un General Assembly resolution." See Canadian Association for Refugees and Forced Migration Studies, "Mandate Refugees," http://rfmsot.appso1.yorku .ca/glossary-of-terms/mandate-refugees/. The MRs enables the resettlement of mandate refugees with a close family member living in the United Kingdom: Government of the United Kingdom, UNHCR Resettlement Handbook, 3. Further details for processing MRS cases are provided in the Asylum Policy Instructions for the program, although they 
remain very broad: Katia Bianchini, "The Mandate Refugee Program: A Critical Discussion," International Journal of Refugee Law 22, no. 3 (June 2010): 370; Uk Border Agency, "Mandate Refugees," 1 June 2012, https://assets.publishing.service.gov.uk/government/uploads/system/uploads/ attachment_data/file/257392/manadaterefugees.pdf. Note: the UK Border Agency guidance cited above replaces a previous Asylum Instruction on Mandate refugees (described in Bianchini), which has been withdrawn for review. The current instruction points to the UNHCR Resettlement Handbook for further information about the GPP and MRS schemes.

77 This included 42,000 Ugandan Asians (1972-4); 22,500 Indochinese (1979-92); 2,500 Bosnians (early 1990s); 4,000 Kosovars (1999): Refugee Council, "Resettling to the UK: The Gateway Protection Programme" (October 2004), accessed 28 January 2019, https://www.refugeecouncil.org .uk/latest/projects/gateway-protection-programme/.

78 Immigration Act, 1971, (UK), c 77.

79 The Act provides for two forms of leave: limited and indefinite: Immigration Act, 1971, s $3(1)$.

80 The United Kingdom makes it an offence to enter the country without such leave: Immigration Act, 1971, s 3; Immigration Rules, Rule 5, https://www.gov.uk/guidance/immigration-rules/immigration-rules-introduction\#intro5; Library of Congress, "Refugee Law and Policy: United Kingdom," http://www.loc.gov/law/help/refugee-law/unitedkingdom .php\#_ftnio.

81 Resettlement Inter-Agency Partnership, "Understanding Resettlement to the UK: A Guide to the Gateway Protection Programme" (Refugee Council, June 2004), https://web.archive.org/web/20120225073106/http://www .refugeecouncil.org.uk/Resources/Refugee\%20Council/ downloads/howwehelp/UnderstandingGPPJune2004 .pdf. Established in 2004, the GPP constitutes the United Kingdom's formal resettlement program, offering "a legal route for up to 750 refugees to settle in the uK each year." Through the GPP, the United Kingdom relies on UNHCR to refer eligible refugees based on criteria set by the UK government through its Asylum Policy Instructions on the GPP. Refugees resettled through the GPP receive indefinite leave to remain in the country. The GPP is overseen by a Resettlement Operations Team within the UK Home Office: UK Visas and Immigration, "Guidance: Gateway Protection Programme," https://www.gov.uk/government/publications/gatewayprotection-programme-information-for-organisations/ gateway-protection-programme. See also El-Enany and Bernhaut, Country Profile: United Kingdom; Bianchini, "Mandate Refugee Program," 369.

82 Nationality, Immigration and Asylum Act 2002, (UK), c 41.

83 Nationality, Immigration and Asylum Act 2002, (UK), c 41, s $59(1)(c)$.

84 Nationality, Immigration and Asylum Act 2002, (UK), c 41, s 59(1)(e).
85 Nationality, Immigration and Asylum Act 2002, (UK), c 41, s $59(2)$.

86 uk Home Office, "Resettlement: Policy Statement," 2018, https://assets.publishing.service.gov.uk/government/ uploads/system/uploads/attachment_data/file/730643/ Resettlement_Policy_document_.pdf.

87 uk Home Office, "Oral Statement by the Home Secretary on Syrian Refugees Delivered on 29 January 2014," 24 January 2014, https://www.gov.uk/government/speeches/ oral-statement-by-the-home-secretary-on-syrian-refugees.

88 uk Home Office, "Syrian Vulnerable Persons Resettlement Scheme (VPRS): Guidance for Local Authorities and Partners," July 2017, https://assets.publishing.service.gov.uk/ government/uploads/system/uploads/attachment_data/ file/631369/170711_Syrian_Resettlement_Updated_Fact_ Sheet_final.pdf, 4; вBC News, "Uк to Accept 20,00o Refugees from Syria by 2020," 7 September 2015, https://www .bbc.com/news/uk-34171148.

89 ввс News, "Uк to Accept 20,000 Refugees."

90 Terry McGuinness, "The uk Response to the Syrian Refugee Crisis," House of Commons Library Briefing Paper Number 06805, 14 June 2017, 11; Carrie Hough, "The UK Government Approach to Syrian-Conflict Refugee Resettlement," 2, https://www.uts.edu.au/sites/default/files/article/downloads/Carrie\%2oHough.United\%2oKingdom. The\%2oUK\%2oGovernment\%20Approach\%20to\%20Syrian-Conflict\%2oRefugee\%20Resettlement.docx; uK Home Office, "Integration of Beneficiaries of International/ Humanitarian Protection into the Labour Market: Policies and Good Practices," May 2016, https://ec.europa .eu/home-affairs/sites/homeaffairs/files/what-we-do/ networks/european_migration_network/reports/docs/ emn-studies/emn-studies-28a_uk_integration_of_ beneficiaries_of_international_protection.pdf, 15 .

91 Hough, "UK Government Approach," 21; UNHCR, "Towards Integration: The Syrian Vulnerable Persons Resettlement Scheme in the United Kingdom," 28, https://reliefweb.int/ sites/reliefweb.int/files/resources/5aoo29174.pdf.

92 uK Home Office, "Vprs Guidance for Local Authorities," 7.

93 Initially, refugees resettled through the VPRS were granted five-year humanitarian protection status. On 22 March 2017, Home Secretary Amber Rudd announced that new VPRS arrivals would receive refugee status, noting that humanitarian protection "does not carry the same entitlements as refugee status, in particular, access to particular benefits, swifter access to student support for Higher Education and the same travel documents as those granted refugee status." VPRS refugees who arrived before 1 July 2017 under humanitarian protection have the opportunity to request a change of status to refugee status: Written Statement by Amber Rudd (Secretary of State for the Home Department), "Syrian Vulnerable Persons Resettlement Scheme and Vulnerable Children's Resettlement Scheme: Arrangements," 22 March 2017, https://www.parliament.uk/ 
written-questions-answers-statements/written-statement/ Commons/2017-03-22/HCWs551. See also "Request to Change Humanitarian Protection Status to Refugee Status" Form, 31 July 2017, last modified 13 August 2018, https:// www.gov.uk/government/publications/request-to-changehumanitarian-protection-status-to-refugee-status.

94 uk Home Office, "Community Sponsorship: Guidance for Prospective Sponsors," last modified 14 December 2008, 6, https://assets.publishing.service.gov.uk/government/ uploads/system/uploads/attachment_data/file/62681o/ Community_sponsorship_guidance_for_prospective_ sponsors_July_2017.pdf.

95 UNHCR, "Resettlement Data Finder," uk Data, https://rsq .unhcr.org/en/\#Mlo5.

96 "Speech by Theresa May to Conservative Conference," 6 October 2015, Electronic Immigration Network, http://www .ein.org.uk/news/home-secretary-use-conservative-partyconference-speech-warn-uk-needs-have-immigrationlimit.

97 2010, c 15, Schedule 23, s. 1(1)(d). The Equality (Community Sponsorship) Arrangement authorized an exception to the application of the Equality Act by allowing the Uk Community Sponsorship Scheme to discriminate by limiting its application to Syrian nationals, arriving to the United Kingdom through the vprs, only, "Equality (Community Sponsorship) Arrangement 2016," 11 July 2016, http://data .parliament.uk/DepositedPapers/Files/DEP2016-0667/ Equality__Community_Sponsorship__Arrangement _2016_-_dated_11.07.2016.pdf.

98 See resources at the following uk Home Office webpages: uk Home Office, "Apply for Full Community Sponsorship," last modified 14 December 2018, https://www.gov. uk/government/publications/apply-for-full-communitysponsorship; and uk Home Office, "Community Sponsorship: How You Can Make It Happen," last modified 24 April 2018, https://www.gov.uk/government/publications/ community-sponsorship-how-you-can-make-it-happen.

99 Government of the United Kingdom, UNHCR Resettlement Handbook UK, 5 .

100 Uk Home Office, "Community Sponsorship," 9.

101 uk Home Office, "Community Sponsorship," 12.

102 Uk Home Office, "Community Sponsorship," 11.

103 UK sponsors are required to provide initial reception support and settlement support for the first year, as well as to have secured housing for two years. See Resettlement Plan template, Ministry of Housing, Communities \& Local Government, Department for International Development and Home Office, "Apply for Community Sponsorship," last modified 14 December 2018, https:/www.gov.uk/ government/publications/apply-for-full-communitysponsorship; uk Home Office, "Community Sponsorship," 11. Resettlement responsibilities include initial reception support and settlement support for the first year, and housing support for two years.
104 The agreement includes requirements for safeguarding sensitive data and legally commits sponsors to fulfilling their responsibilities toward the sponsored refugees, as outlined in their settlement plan, which is attached as an annex to the agreement: uk Home Office, "Sample Agreement Relating to the Provision of Full Community Sponsorship," 14 December 2018, https://assets.publishing.service. gov.uk/government/uploads/system/uploads/attachment_ data/file/554049/2016-09-16_SAMPLE_Full_Community_ Sponsorship_Agreement_for_govuk.pdf.

105 uk Home Office, "Community Sponsorship," 14.

106 Once a family is proposed, both the sponsors and the local authority must confirm the match within five days. UK Home Office, "Community Sponsorship," 16.

107 UK Visas and Immigration and The Right Honourable Caroline Nokes MP, "Home Office Awards $£ 1$ Million to Help Communities Support Refugees" news story, 18 June 2018, https://www.gov.uk/government/news/home-officeawards-1-million-to-help-communities-support-refugees. Within a year of its new Community Sponsorship Scheme, the United Kingdom granted funding to Reset, an umbrella organization mandated to help sponsors prepare to welcome refugees into their communities: See Reset's website: https://www.resetuk.org/. By contrast, the development of training for sponsors in Canada came two decades into its model through the Refugee Sponsorship Training Program (RSTP), and national-level coordination of sponsorship agreement holders through the saH Association. The RSTP provides optional training and support to sponsors of all types across Canada. The SAH Association represents the interests of SAHs across Canada, liaising with the government of Canada through an elected council funded by the government: See RSTP website: http://www.rstp.ca/. See also website of the Canadian SAH Association: http://www. sahassociation.com/.

108 In the emergence of several dedicated full-time positions in the uk Home Office and multiple new NGos dedicated to growing and supporting the sponsorship scheme. See, e.g. Sponsor Refugees, http://www.sponsorrefugees.org/.

109 Including Europeans escaping political oppression in the nineteenth century, Chileans fleeing military dictatorship the 1970 s and 1980s, Indochinese refugees in the late 1970s and 1980s, and Bosnian refugees in the 1990s: Marie-Charlotte de Lapaillone, for the United Nations Association of New Zealand, "New Zealand's Approach to Refugees: Legal Obligations and Current Practices," policy paper 1 (October 2012), 1-2, http://nzcgs.org.nz/wp-content/uploads/ 2013/11/2012-UNANZ-Policy-Paper-01-2012-Refugees.pdf. See also J. Marlowe and S. Elliott, "Global Trends and Refugee Settlement in New Zealand," Kōtuitui: New Zealand Journal of Social Sciences Online 9, no. 2 (2014): 44, https:// doi.org/10.108o/1177083X.2014.953186.

110 Marlowe and Elliott, "Global Trends," 44. Until recently, the rate of resettlement has been 750 per year. Ministry 
of Business, Innovation \& Employment, "Briefing for the Incoming Minister of Immigration," 26 October 2017, 5, https://www.beehive.govt.nz/sites/default/files/2017-12/ Immigration.pdf. See also Immigration New Zealand, “Operational Manual," last modified 17 December 2018, F3.5(b), https://www.immigration.govt.nz/opsmanual/ \#35439.htm.

111 Mike Mika, "Immigration Act: Key Changes," Southland Times, 9 November 2010, http://www.stuff.co.nz/ southland-times/columns/4313985/Immigration-Act-key -changes. The 1987 Immigration Act already contained extensive provisions around refugee protection: see Immigration Act, 1987, 1987 No 74, as repealed by 2009 No 51, s 404.

112 Immigration Act, 2009, 2009 No 51, s 124(a).

$113 \mathrm{NZ}$ Immigration Act, s 126(b).

114 NZ Immigration Act, ss 22(1), 22(5)(b).

115 NZ Immigration Act, s 22(5)(a).

116 Ministry of Business, Innovation \& Employment, "Briefing for the Incoming Minister," 7.

117 UNHCR, "Resettlement Data Finder," NZ Data, https://rsq .unhcr.org/en/\#Do5B.

118 Ministry of Business, Innovation \& Employment, "Briefing for the Incoming Minister," 5.

119 Cabinet Office, "Cabinet Economic Growth and Infrastructure Committee, Minute of Decision: Community Organisation Refugee Sponsorship Category," https://web .archive.org/web/20180201100844/http://www.mbie.govt .nz/info-services/immigration/oia-responses/foldercommunity-organisation-refugee-sponsorship-category/ cabinet-egi-minute-community-organisation-refugeesponsorship-category.pdf [NZ Cabinet Minute of Decision]. The decision was heavily informed by a detailed background paper: Cabinet Economic Growth and Infrastructure Committee, "Community Organisation Refugee Sponsorship Category," (2017) para 2, https://www.mbie .govt.nz/assets/a28c781f78/cabinet-paper-communityorganisation-refugee-sponsorship-category.pdf[nzCabinet Paper 2017].

120 NZ Cabinet Paper 2017, at 1, para 3.

121 Jacinda Ardern and Iain Lees-Galloway, "Refugee Quota Increases to 1,500 in 2020," 19 September 2018, https://www.beehive.govt.nz/release/refugee-quotaincreases-1500-2020.

122 Which, in turn, reflects the adoption of recommendations set out in the detailed background paper, referenced in NZ Cabinet Paper 2017.

123 NZ Cabinet Minute of Decision, 5.1-5.3.

124 NZ Cabinet Minute of Decision, 6.1-6.5. The NZ Cabinet Minute of Decision also delineates the responsibilities of the New Zealand government, which include: providing sponsored refugees with access to public welfare services, housing support, education, and health services, as well as assessing the selection and screening of sponsored refugees and their initial reception at the Mangere Refugee Resettlement Centre.

125 NZ Cabinet Minute of Decision, 4-5.

126 NZ Cabinet Minute of Decision, 7.1 and 7.2.

127 See a list of Regulations on the website of Immigration New Zealand, Ministry of Business Innovation \& Employment, "Immigration Law," 3, https:// www.immigration.govt.nz/about-us/policy-and-law/ legal-framework-for-immigration.

128 Immigration New Zealand, "Operational Manual," F4.20.

129 Ministry of Business, Innovation \& Employment, "Briefing to the Incoming Minister," 5.

130 NZ Cabinet Minute of Decision, 11.4. The Mangere Refugee Resettlement Centre is a nationally run welcoming facility where newcomers receive orientation supports to prepare them for settlement in communities across the country.

131 Via instructions introduced through Amendment Circular 2017-14: Ministry of Business, Innovation \& Employment, Immigration New Zealand Instructions: Amendment Circular No. 2017/14, 21 December 2017, https://www.immigration.govt.nz/documents/amendment-circulars/amendment-circular-2017-14.pdf.

132 Eligible refugees interested in the community sponsorship program may submit an expression of interest in the program to an immigration officer or be invited to submit such an expression of interest by an immigration officer. Expressions of Interest will be entered into a pool and remain valid for six months. Refugees may submit an application for community sponsorship only if invited to do so. Once an application is submitted, New Zealand Immigration will grant a permanent resident visa if there is a sponsorship group for that refugee and the principal applicant meets requirements outlined in the Cabinet decision: Immigration New Zealand, "Operational Manual," F4.25.10; 4.25.20; 4.25.30.

133 New Zealand Ministry of Business, Innovation \& Employment, "Request for Applications (RFA) for the Pilot of the CommunityOrganisation RefugeeSponsorshipCategory," 13 October 2017, https://web.archive.org/web/20180417055250/ http://www.mbie.govt.nz/info-services/immigration/ community-organisation-refugee-sponsorship-category/ cors-request-for-application.pdf.

134 New Zealand Ministry of Business, Innovation \& Employment, "Deed of Agreement for Services: Pilot of the Community Organisation Refugee Sponsorship Category," accessed 3 October 2018, https://web.archive.org/web/ 20180201105014/http://www.mbie.govt.nz/info-services/ immigration/community-organisation-refugee-sponsorship-category/cors-deed-of-agreement-for-services.pdf.

135 New Zealand Ministry of Business, Innovation \& Employment, "Request for Applications (RFA)," 8-9, 14. Responsibilities include providing domestic travel from the Mangere Refugee Resettlement Centre to the settlement location in the community; the arrangement of housing, 
furniture, and furnishings; providing community orientation and settlement assistance by connecting refugees to services in their new community; and providing support in employment search. New Zealand Ministry of Business, Innovation \& Employment, "Deed of Agreement," annex 1 of appendix A.

136 New Zealand Ministry of Business, Innovation \& Employment, "Deed of Agreement, 18.2-18.3.

137 New Zealand Government, "Community Organisations Chosen to Sponsor Refugees in NZ," press release, Community Scoop, 26 January 2018, http://community.scoop. co.nz/2018/o1/community-organisations-chosen-tosponsor-refugees-in-nz/.

138 "First Refugees Arrive under New Community Sponsorship Category," Newshub, 6 July 2018, https://www.newshub .co.nz/home/new-zealand/2018/o7/first-refugees-arriveunder-new-community-sponsorship-category.html.

139 Core Community Partnership, "Proposal to Confirm Community Sponsorship as a Permanent Pathway for Resettlement," 12 November 2018, https://www.swbc.org.nz/ wp-content/uploads/2018/11/20181112-Community-Sponsorship-Proposal.pdf; Amnesty International, Community Sponsorship of Refugees: New Zealand's Pilot Programme and Its Potential, 2018, https://static1.squarespace.com/ static/5adea6a089c1722c3aedof82/t/5bf4a4468985837266 o8focd/1542759605586/AI_Shadow_Report_Final_Final_ Web_Spreads-ilovepdf-compressed.pdf.

140 Meg de Ronde, "The Community Have Proved They Can Change Refugees' Lives. Let's Not Quit Now," Spinoff, 27 November 2018, https://thespinoff.co.nz/ society/27-11-2018/the-community-have-proved-theycan-change-refugees-lives-lets-not-quit-now/. See also Amnesty International New Zealand, "I Welcome Pledge," https://www.iwelcome.org.nz/report.

141 Collette Devlin, "Govt Urged to Make Refugee 'Community Sponsorship' Pilot Programme Permanent," stuff, 27 November 2018, https://www.stuff.co.nz/national/politics/ 108889889/govt-urged-to-make-refugee-communitysponsorship-pilot-programme-permanent.

142 UNHCR, "States Parties to the 1951 Convention." Argentina also ratified the Additional Protocol on 6 December 1967.

143 Maria-Julia Contardi and Nazli Zaki, "Through Thick and Thin: The Evolution of UNHCR's Work in Argentina," UNHCR, 3 April 2006, http://www.unhcr.org/afr/news/ latest/2006/4/44313ed84/thick-thin-evolution-unhcrswork-argentina.html. Refugees from countries like Democratic Republic of the Congo, Pakistan, Sierra Leone, Liberia, Iraq, Guinea, Ghana, Nigeria, Armenia, and Chechnya would seek asylum in Argentina.

144 See generally, Dirección Nacional de Población, Refugiados del Sudeste Asiático en la Argentina, 7 November 2012, http:// www.mininterior.gov.ar/poblacion/pdf/Documentoo7.

145 Argentina created its Solidarity Resettlement program by signing a Memorandum of Understanding with the UNHCR to implement its commitments to responsibility-sharing outlined in the Mexico Declaration and Plan of Action to Strengthen the International Protection of Refugees in Latin America, 16 November 2004, http://www.refworld .org/docid/424bf6914.html. The Plan of Action encouraged Latin American states to introduce legislation relating to refugees and human rights and to "redouble their efforts to provide protection, assistance and find adequate solutions for refugees in the region" (preamble). The Mexico Declaration was adopted on the twentieth anniversary of the adoption of the Cartagena Declaration and was seen by signatory states as a means to demonstrate their commitment to the principles of refugee protection established in the latter. See Hiram Ruiz, "Evaluation of Resettlement Programmes in Argentina, Brazil, Chile, Paraguay, and Uruguay," UNHCR, December 2015, http://www.unhcr.org/57c983557.pdf. See also Paulo Cavaleri, "Argentina: Resettling Refugees within the Context of an Open Migration Policy," Forced Migration Review 40 (2012): 49, https://www.fmreview.org/sites/ $\mathrm{fmr} /$ files/FmRdownloads/en/young-and-out-of-place/ cavaleri.pdf. Argentina's General Law of Recognition and Protection of Refugees, Law No. 26.165 (8 November 2006) strengthened the legal infrastructure underpinning the Solidarity Resettlement Program and Argentina's domestic refugee program by creating the National Refugee Committee (CONARE) and "fully regulat[ing] the process for determining refugee status and the rights and guarantees of asylum and refugee applicants." In relation to the Solidarity Resettlement Program, CONARE was charged with liaising with the UNHCR and its consulates abroad to identify eligible candidates for resettlement and coordinate the issuance of visas and travel documents in accordance with an annual work plan. See UNHCR, UNHCR Resettlement Handbook: Argentina Country Chapter (last modified June 2013), https://www.unhcr.org/4b7bc3a19.pdf\#zoom=95.

This program remained operational until 2013. See S. Michelle Alfaro and Martin Lettieri, "In Search of Sustainable Refugee Resettlement Solutions for Latin America," Revista Jurídica de Buenos Aires 42, no. 95 (2017): 237. See also Ruiz, "Evaluation of Resettlement Programs," 3, 25. The Solidarity Resettlement Program was unsustainable because it relied on international funds and insufficient domestic ownership over the programs. According to Alfaro and Lettieri, "In Search of Resettlement Solutions for Latin America," 237, "Without the continued financing of the international community and with the region sliding into an economic downturn, Argentina was unlikely to prioritize the needed funding from its budget to support a resettlement program."

146 Law 25,871 (20 January 2004), arts 1, 21. Argentina has also legislated refugee protection through its General Law of Recognition and Protection of Refugees.

147 The General Law of Recognition and Protection of Refugees, art 4, incorporated the extended definition of refugee established in the third conclusion of the 1984 Cartagena Declaration on Refugees, which includes individuals 
forced to flee their homes in response to general violence, foreign aggression, internal conflict, widespread human rights violations, and other circumstances that gravely disturb public order: Cartagena Declaration on Refugees in Central America, Mexico and Panama, 22 November 1984, http://www.refworld.org/docid/3ae6b36ec.html; Cavaleri, "Argentina: Resettling Refugees."

148 Argentina's Migration Law, arts $23(\mathrm{~m}), 34$. Article $23(\mathrm{k})$ provides that recognized refugees and asylum seekers will be granted two-year renewable residence permits. While individuals resettled to Argentina for humanitarian reasons by virtue of Article 23 $(\mathrm{m})$ are not formally recognized as refugees under the Refugee Convention definition, they may petition Argentina for Convention refugee protection once they have arrived on its territory.

149 Argentina National Directorate of Migration, "Special Humanitarian Visa Program: Integration," 12 July 2018, https://www.argentina.gob.ar/programa-siria/acerca-delprograma.

150 The presidential decrees were issued under the president's constitutional authority to create "instructions and rules necessary for the enforcement of the laws of the nation, without altering their spirit with regulatory exceptions." Constitution of the Argentine Nation, 1994, s. 99(2), http:// www.biblioteca.jus.gov.ar/argentina-constitution.pdf.

151 Argentina: Decreto 616/2010-Reglamentación de la Ley de Migraciones No. 25.871 y sus modificatorias (6 May 2010), https://www.refworld.org/docid/4be2de512.html [Decree 616/2010]. In Argentina, decrees are orders prescribed by members of the executive and ministers. See Ministerio de Coordinación de Gabinete, Seguridad y Trabajo, Decreto No. 1449/oo: Reglamento para la elaboración de proyectos de leyes, decretos, resoluciones y disposiciones: Decreto No. 144 (30 June 2000), http://capacitacion.hcdn.gob.ar/wp-content/ uploads/2015/10/Dec.-N\%C2\%BA-1449-oo-Regl-elabnormas-NEUQUEN.pdf.

152 Decree 616/2010, preamble. The decree set out the roles and responsibilities for this new agency, including its mandate to collaborate with other entities and levels of government to ensure the successful integration of newcomers: see annex I, arts 6, 14.

153 Decree 616/2010, annex I, art 3.

154 Gabinette Nacional del Programa Siria, Decreto No. 1034/2016 (16 September 2016), http://servicios.infoleg.gob. ar/infolegInternet/anexos/26500o-269999/265715/norma .htm [Decree 1034/2016]. The Cabinet includes the chief of the Cabinet of ministers and heads of the Ministry of the Interior, Public Works, and Housing; Ministry of Foreign Affairs; Ministry of Social Development; Ministry of Education and Sports; Ministry of Labour, Employment and Social Security; Ministry of Health; Ministry of Justice and Human Rights; Ministry of Security; Ministry of Culture; and the Federal Intelligence Agency: See Decree 1034/2016, art 2.

155 Decree 1034/2016, preamble, art 1 . As the program was structured at the time of writing, all refugees resettled through the Syria Program were resettled with the assistance of family or community sponsors. To facilitate its coordination function, the national Cabinet was mandated to create general guidelines for the settlement and integration of refugees affected by the Syrian conflict.

156 Decree 1034/2016, preamble, art 3.

157 Argentina has also pledged to grant 1,000 scholarships to Syrian refugees on top of the 3,000 commitment. See Oliver Griffin, "Argentina Grants 1,00o Scholarships to Syria Refugees, Urges Others to Follow," Reuters, 7 April 2017, https://www.reuters.com/article/ us-argentina-refugees-scholarships-idUSKBN1792PU.

158 Provisions are decisions issued by senior administrative authorities such as undersecretaries and heads of decentralized administrative bodies on questions within their area of expertise. See Decree No. 1449/oo. See also Ministerio de Coordinación de Gabinete, Seguridad y Trabajo, "Glosario de Términos," http://www.trabajo.gov.ar/ downloads/manualProcedimientos/titulopreliminar-capII.pdf.

159 As further defined by the 2010 Presidential Decree. See decree 616/2010.

160 Disposición DNM 3915/2014 (14 October 2014), https://www .refworld.org.es/pdfid/5a8de92c4.pdf [Provision 3915/2014], annex I, arts 1, 5(a)(i); Family relationship understood in a broad sense, including relatives until the fourth degree, regardless of age. See Provision 3915/2014, annex I, art 5(a) (ii).

161 Provision 3915/2014, annex I, art 5(a)(iii).

162 Provision 3915/2014, annex I, art 5(a)(iii).

163 Demian Bio, "Macri Says Argentina Will Welcome Even More Syrian Refugees," Bubble, 20 September 2016, http:// www.thebubble.com/macri-says-argentina-will-welcomeeven-more-syrian-refugees/; Frederick Bernas, "Syrian Refugees Reap Benefits of Argentina's New Visa Rules" UNHCR, 10 November 2017, http://www.unhcr.org/news/ stories/2017/11/5a0586774/syrian-refugees-reap-benefitsargentinas-new-visa-rules.html.

164 Ministerio del Interior, Obras Públicas y Vivienda, Disposición DNM 4683/2016 (5 September 2016), http://www. refworld.org.es/pdfid/5a8de1c34.pdf [Provision 4683/2016].

165 Callers must be Argentinian citizens or residents. In addition to the letter of invitation cited above, they must also provide identification documents and a certificate proving residence from the Argentinian Federal Policy. See Provision $4683 / 2016$, arts $3(1)(\mathrm{c}) ; 9(\mathrm{a})$.

166 Provision 4683/2016, art 3(1)(a); 3(2)(b).

167 Provision 4683/2016, art 3(1)(b). Applications submitted with guarantee letters will be treated with greater flexibility by the National Directorate for Migration.

168 Argentina Dirección Nacional de Migraciones, "Acerca Del Programa [About the Program]," https://www.argentina .gob.ar/programa-siria/acerca-del-programa. If sponsoring directly, requesters must be enrolled in the National Directorate for Migration's National Registry for Foreign 
Applicants for organizations requesting admission of any foreigners into Argentina. The registry establishes extra safeguards for the process of organizations (including, e.g., employers hiring foreign workers, or education institutions) to seek admission of foreigners to Argentina by, inter alia, vetting their legal status and financial capacity, and imposing reporting requirements: "Dirección Nacional de Migraciones, Disposición 54.618/2008: Modificación de la Disposición No 56.647/2005, mediante la cual se creó el Registro Nacional Único de Requirentes de Extranjeros" (29 July 2008), http://www.migraciones.gov.ar/pdf_varios/ residencias/disposicion-dnm-54618-08.pdf. In addition to non-government or other organizations, municipalities and provinces may also act as requestors, as demonstrated by the province of San Luis: UNHCR, "Argentina: Dos nuevas familias llegaron a la Provincia de San Luis en el marco del Programa Siria," 24 July 2018, http://www.acnur.org/ noticias/noticia/2018/7/5b58a7c24/argentina-dos-nuevasfamilias-llegaron-a-la-provincia-de-san-luis-en-el.html.

169 The Syria Program still requires, however, the specification of some link between sponsors and refugees. This link can be tangential, such as through an organization or institution that matches callers and requestors to eligible refugee families in need of assistance: Provision 4683/2016, art 3(3).

170 Specifically, the province of San Luis has "requested the support of the UNHCR to identify and refer Syrian refugees in Lebanon to the Humanitarian Visa program." See Alfaro and Lettieri, "Resettlement Solutions for Latin America," 239.

171 Provision 4683/2016, art 13.

172 Decree $1034 / 2016$, art 3. The National Directorate for Migration coordinates the activities of the working group with UNHCR and the International Organization for Migration, which include holding regular meetings with key stakeholders at local, provincial, and national levels: Argentina National Directorate of Migration, "Special Humanitarian Visa Program: Integration," 12 July 2018, https://www .argentina.gob.ar/programa-siria/acerca-del-programa.

173 UNHCR, "Emerging Resettlement Countries Joint Support Mechanism (ERCM)," http://reporting.unhcr.org/sites/ default/files/Information\%2OSheet\%2Oon\%2OERCM\%2O September\%202016.pdf; Bernas, "Syrian Refugees Reap Benefits." This support is also authorized by art 9(c) of Provision $4683 / 2016$. The ERCM provides financial support and technical assistance to emerging resettlement countries like Argentina to achieve three main objectives: (1) providing a mechanism for governments, private sponsors and donors to harness their expertise and contribute both financially and technically to supporting refugee resettlement and the world in a strategic and coordinated manner; (2) assisting new and emerging resettlement countries in assessing the sustainability of their resettlement programme, helping to identify vulnerable areas in need of support and providing, accordingly, targeted financial and/or technical assistance; (3) channelling and supporting the sharing of technical expertise and good practices among resettlement countries, international organizations, international NGOS and governmental and non-governmental actors in new and emerging resettlement countries.

174 Delegation of the European Union to Argentina, "La Unión Europea apoya a la Argentina en su política de recepción e integración de refugiados," press release, 17 June 2018, https://eeas.europa.eu/delegations/argentina/47534/ node/47534_es.

175 UNHCR, "Argentina: Dos nuevas familias llegaron a la Provincia de San Luis en el marco del Programa Siria," 24 July 2018, http://www.acnur.org/noticias/noticia/2018/7/5b58a7c24/ argentina-dos-nuevas-familias-llegaron-a-la-provinciade-san-luis-en-el.html.

176 Argentina Ministerio de Relaciones Exteriores y Culto, "Joint Press Release: Meeting between Foreign Minister Faurie and the United Nations High Commissioner for Refugees (UNHCR)" (10 October 2018), http://enaun.mrecic .gov.ar/en/joint-press-release-meeting-between-foreignminister-faurie-and-united-nations-high-commissioner.

177 Alfaro and Lettieri, "Resettlement Solutions for Latin America," 239.

178 UNHCR, "States Parties to the 1951 Convention," Additional Protocol, art 1(1); Joan Fitzpatrick, "The International Dimension of U.S. Refugee Law," Berkeley Journal of International Law 15, no. 1 (1997): 1, 4.

179 Refugee Council usa, "History of the U.S. Refugee Resettlement Program," http://www.rcusa.org/history/.

180 The USRAP comprises the Bureau of Population, Refugees and Migration of the U.S. Department of State; the U.S. Citizenship and Immigration Service of the U.S. Department of Homeland Security; the Office of Refugee Resettlement of the U.S. Department of Health and Human Services; five international or non-governmental organizations that operate resettlement support centres around the world under the supervision and funding of the Bureau of Population, Refugees and Migration of the U.S. Department of State; nine domestic nongovernmental organizations with about 350 affiliated offices across the United States; and thousands of private citizens who volunteer their time and skills to help refugees resettle in the United States. See U.S. Department of State, "Refugee Admissions," https://www .state.gov/j/prm/ra/admissions/.

181 Claire Felter and James McBride, "How Does the U.S. Refugee System Work?" Council on Foreign Relations, last modified 10 October 2018, https://www.cfr.org/backgrounder/ how-does-us-refugee-system-work.

182 Felter and McBride, "How Does the U.S. Refugee System Work?"; Jens Manuel Krogstad and Jynnah Radford, "Key Facts about Refugees to the U.S.," Pew Research Center, 30 January 2017, http://www.pewresearch.org/ fact-tank/2017/o1/3o/key-facts-about-refugees-to-the-u-s/; uNHCR, "Resettlement Data Finder," us 2016 Data, https:// rsq.unhcr.org/en/\#1Bz6.

183 UNHCR, "Resettlement Data Finder," us 2017 Data, https:// rsq.unhcr.org/en/\#eBr7. 
184 UNHCR, "Resettlement Data Finder," us 2018 Data, https:// rsq.unhcr.org/en/\#Ids7.

185 UNHCR, "Resettlement Data Finder," us 2003-2018 Data, https://rsq.unhcr.org/en/\#JJ6r.

186 U.S. Citizenship and Immigration Services, "Immigration and Nationality Act," https://www.uscis.gov/laws/ immigration-and-nationality-act.

187 Immigration and Nationality Act, (Us), 8 UsC 1158, s 207 (a) (2) [INA]. The provision further enables the president to permit the resettlement of certain refugees in specific emergencies in addition to the annual quotas $(207(b))$. The INA incorporates the Refugee Act of 1980, which for the first time incorporated the Convention definition of refugee into U.S. law: Refugee Council USA, "History of the U.S. Refugee Resettlement Program," http://www.rcusa.org/ history/.

188 U.S. Department of State, "U.S. Refugee Admission Program," https://www.state.gov/j/prm/ra/admissions/index. $\mathrm{htm}$. Potential cases are referred to one of nine resettlement support centres around the world operated by international and non-governmental organizations and funded and managed by the U.S. Department of State's Bureau of Population, Refugees and Migration. Refugees are interviewed and vetted by the U.S. Department of Homeland Security and undergo a health screening before being approved for travel to the United States.

189 INA, S. 209(a)(2); UNHCR Resettlement Handbook, "Country Chapter: USA," (July 2018), accessed 28 January 2019, 10, http://www.unhcr.org/3c5e5a764.html.

190 INA, S 411. The INA further mandates the ORR to ensure sufficient funding for employment training and placement, language training, and cash assistance to resettled refugees: INA, S 412(1)(A). It also provides that employable refugees should be placed in jobs as soon as possible after arrival in the United States, that available social services should be focused on employment acquisition, language training, and case management, and that "local voluntary agency activities should be conducted in close cooperation and advance consultation with State and local governments": INA, s 412(1)(B).

191 INA, s. 412(2)(C).

192 INA, s. 412(10)(A)(ii).

193 U.S. Department of State, "Refugee Admissions," https:// www.state.gov/j/prm/ra/admissions/; Refugee Processing Centre, "R\&P Agency Contacts," http://www.wrapsnet .org/rp-agency-contacts/. The current nine resettlement agencies are Church World Services, Ethiopian Community Development Council, Episcopal Migration Ministries, Hebrew Immigrant Aid Society, International Rescue Committee, Lutheran Immigration and Refugee Service, U.S. Committee for Refugees and Immigrants, United States Conference of Catholic Bishops/Migration and Refugee Services, and World Relief. See also Refugee Council UsA, "History of the U.S. Refugee Resettlement Program," http://www.rcusa.org/history/.
194 The duration of this responsibility was a minimum of thirty days and up to ninety days after the refugees' arrival. UNHCR Resettlement Handbook USA, 10.

195 UNHCR Resettlement Handbook USA, 10.

196 A map of Reception and Placement Program Affiliate Sites in 2017 can be viewed on the website of Cultural Orientation Resource Exchange: "Who We Serve," https:// coresourceexchange.org/who-we-serve/.

197 Some examples include RefugeeOne, "Co-Sponsorship Package," http://www.refugeeone.org/uploads/1/2/8/1/12814267/ co_sponsor_packet.pdf; Canopy Northwest Arkansas, Cosponsorship Handbook: 2016, https://static1.squarespace .com/static/57eaaa21d2b857ed $94 \mathrm{~d} 16 \mathrm{fde} / \mathrm{t} / 57 \mathrm{f}_{3} \mathrm{~cd} 8 \mathrm{bff} 7 \mathrm{c50}$ d6307f9568/1475595660493/Co-Sponsorship+handbook .pdf; Minnesota Council of Churches Refugee Services, "Cosponsorship," http://www.mnchurches.org/refugeeservices/ get-involved/church-and-group-opportunities/co-sponsorship; HIAs Chicago, "Congregational Co-Sponsorship Program," http://static1.1.sqspcdn.com/static/f/901119/ 7404628/1483924108363/HIAS+Chicago+Co-Sponsorship +Program_Info+Packet.pdf?token $=$ us\%2BYk4WlGuOM mB87lP2TkxclRGQ\%3 D.

198 The closest the us government has come to a formal program was a 2016 announcement indicating interest in a program: "Top State Department officials voiced their support for private sector programs that can enhance resettlement capacity in the country. It was announced that the State Department was working in conjunction with Refugee Council USA-the umbrella organization that represents the nine charities that resettle refugees across the countryin crafting details for a private refugee sponsorship pilot program [that was] to launch in 2017." However, the new administration elected in November 2016 did not continue this work: Matthew La Corte, "Let the U.S. Resettle Refugees Privately," Refugees Deeply, 17 November 2016, https:// www.newsdeeply.com/refugees/community/2016/11/17/ let-the-u-s-resettle-refugees-privately.

199 Episcopal Migration Ministries and Church World Service. See Integrated Refugee \& Immigrant Services, Community Co-Sponsorship Program: Manual for Refugee Resettlement-August 2016, 4-5, http://www.irisct.org/wp-content/ uploads/2016/04/CO-SPONSORSHIP-MANUAL.August.2016 .pdf.

200 Integrated Refugee \& Immigrant Services, "Getting Started: Co-sponsorship," September 2016, http://www.irisct.org/ getting-started/.

201 Integrated Refugee \& Immigrant Services, Community CoSponsorship Program, 8.

202 Integration Refugee \& Immigrant Services, "Getting Started: Co-sponsorship," September 2016, http://www. irisct.org/wp-content/uploads/2016/10/Sept.2016.getting .started.pdf.

203 Integrated Refugee \& Immigrant Services, Community CoSponsorship Program, 5, 7. 
204 Integrated Refugee \& Immigrant Services, "History," http:// www.irisct.org/history/.

205 Integrated Refugee \& Immigrant Services, Community CoSponsorshipProgramManual-October2018Edition,3, http:// www.irisct.org/wp-content/uploads/cs-portal/forms/ RESOURCE \% 2 O D O C S / PRE - A RRIVAL/ COMM \% 2 O C O SPONSORSHIP\%2OOCTOBER\%2O2O18\%2OMASTER\%2OCOPY .pdf.

206 The United Kingdom would be free to change its policy and apply its Community Sponsorship Program to other resettlement programs like the GPP.
Jennifer Bond is an associate professor at the University of Ottawa, the founder and managing director of the University of Ottawa Refugee Hub, and chair of the Global Refugee Sponsorship Initiative. She can be contacted at jennifer.bond@ uottawa.ca.

Ania Kwadrans is a human rights lawyer and senior legal and policy advisor at the Refugee Hub. She can be contacted at ania.kwadrans@refugeehub.ca. 